\title{
GROWTH IN STILL'S DISEASE
}

\author{
BY \\ B. M. ANSELL AND E. G. L. BYWATERS \\ From the Special Unit for Juvenile Rheumatism, Canadian Red Cross Memorial Hospital, Taplow, Bucks, \\ and the \\ Department of Medicine, Postgraduate Medical School, London
}

(RECEIVED FOR PUBLICATION SEPTEMBER 28, 1956)

The factors governing normal growth in man are complex and their inter-relationships need clarification. Much of our knowledge is based on assumptions derived from experiments in other species: in man observation of the modification of growth by disease and its treatment has been the only direct mode of inquiry. Such diseases may be classified as:

(a) general disturbance of a long-lasting nature, e.g. congenital heart disease (Adams and Forsyth, 1951; Campbell and Reynolds, 1949; Lund, 1952), diabetes mellitus (Bogan, 1940; Beal, 1948; Hernberg and Heikel, 1951), allergic disorders (Cohen, Weller, and Cohen, 1940; Cohen and Abram, 1948; Welsh, 1951), bronchiectasis (Findlay and Graham, 1927), blood diseases such as primary polycythaemia (Halbertsma, 1933), and congenital haemolytic anaemia (Langston, 1935), chronic renal disease (Ellis and Evans, 1933), or the sequel to atomic explosions (Greulich, Crismon, and Turner, 1953).

(b) local disturbances of nutrition, metabolism and function, e.g. joint tuberculosis (Gill, 1944; Sissons, 1952), osteomyelitis, angioma, poliomyelitis (Harris, 1930), infantile hemiplegia or post-encephalitic Parkinsonism (Gaunt, 1949).

(c) Certain endocrine and metabolic diseases specifically affect bone growth throughout the body, e.g. hypothyroidism, rickets (either primary or secondary), and pituitary disorders.

Rheumatoid arthritis in children or Still's disease offers a favourable opportunity of studying the inter-relationship of these various factors in growth, since not only is there a local disturbance of growth due to nearby joint disease but there is also a general disturbance of metabolism. Furthermore, the picture may be modified by the effects of treatment, which again may act on the body as a whole or by suppression of local inflammation.

\section{Material}

We have, therefore, undertaken a survey of the general growth and bone development in 119 children suffering from Still's disease seen at this unit within the period 1948-1953, in whom the disease started before the age of 14. The age and sex distribution of this group (Fig. 1, overleaf) corresponds with that in the largest series hitherto published (Coss and Boots, 1946; Edström, 1947; Sury, 1952). It should be pointed out, however, that in contrast to other series, such as those of Coss and Boots (1946) and Barkin (1952), many children were referred here in the early stages of their disease.

This series is selected only by reference to hospital and by the exclusion of four children in whom the diagnosis was not beyond doubt at the time when this analysis was begun. Within the group of 119 , height and weight data were not analysed in three cases in whom the disease had commenced before the age of 5 years, and in fifteen cases with onset between 5 and 14 years, either because of associated disease (asthma, oesophageal stricture, and congenital heart disease: three cases) or because of inadequate records (fifteen cases).

The wrist and hand $x$ rays were examined in all cases, as well as $x$ rays of other joints, as indicated clinically. Radiographs from three additional subjects, diagnosed after the conclusion of the study, are also used for illustration.

All patients were treated with a good general diet, physiotherapy, adequate rest, splintage, analgesics, iron, and blood transfusion where necessary. Six patients were treated in addition with methyl testosterone $25 \mathrm{mg}$./day by mouth for one or two 6-week periods, and data on a further case treated thus, not in this series because her disease commenced at 15 years, are also surveyed. Twelve patients who were seen within 9 months of the onset of the disease were treated with oral cortisone acetate in sufficient quantity to suppress symptoms (the dose varying from $25-150 \mathrm{mg}$./day) and continued thus as long as disease activity was thought to be present. No case was treated for less than 3 months and most of these patients received continuous hormone for at least one year. Six more patients received hormone therapy in a similar way, but in these cases the 


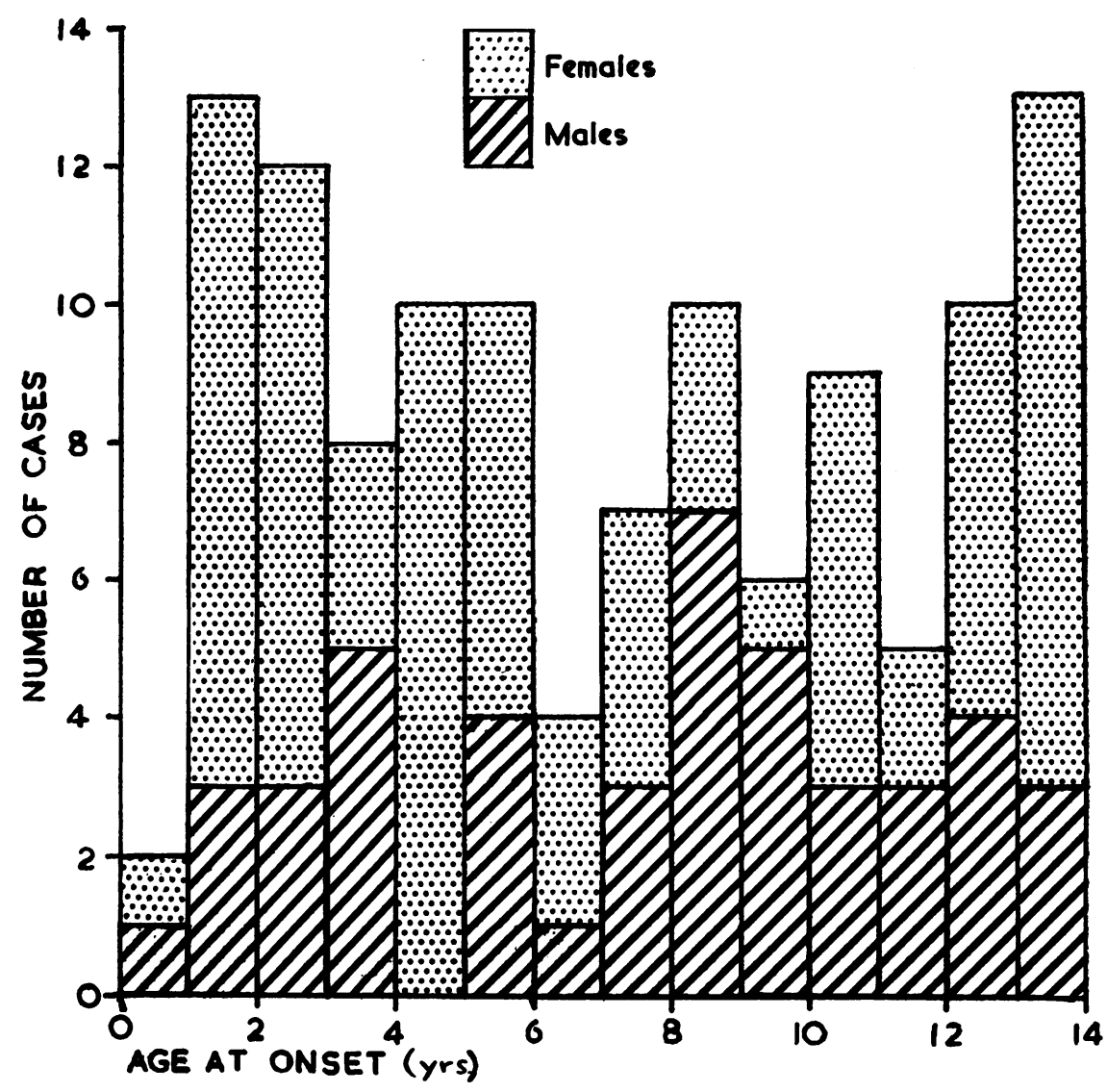

Fig. 1.-Age at onset and sex distribution of 119 cases of Still's disease.

use of the drug was begun considerably later in the course of the disease. Once any form of hormone therapy was started, subsequent data were considered separately as part of the hormone-treated group. The remaining 95 patients were treated conservatively as indicated above.

\section{Methods}

Height and weight were measured when the patient was first seen, during hospital treatment, and at regular intervals after discharge. The heights were taken standing, since recumbent measures were found to be inaccurate, sometimes showing differences of several inches. In cases with flexion deformities of the hips and/or knees, the heights were not used for comparison. $X$ rays were taken of both hands and wrists on entry, at intervals during the stay in hospital, and at the annual follow-up examinations. For the purpose of analysis these $x$ rays were considered in three groups:

(1) Those patients in whom there was no clinical evidence of wrist involvement at any time,

(2) Those who had shown clinical involvement of the hand or wrist for a period of 3 months or less (and had then returned to normal),

(3) Those in whom the hand or wrist joints hap. been involved continuously for more then 3 months.

The measurements of height, weight, and skeleta. development selected for analysis were those taken at the patient's first and subsequent annual visits.

Assessment of growth in weight and height has been by comparison with a mean normal range established by Holt and McIntosh (1941) for 0-5 years and that given $p$ by the Ministry of Health for schoolchildren aged 5-1 years (Menzies, 1940), the results being expressed as a percentage above or below this mean standard lever It is recognized that these standards are relative and than adjustments may be needed for comparison with presentu day populations. Indeed, while this analysis was in progress, a further report was made by the Londos County Council (Daley, 1950) which suggests that London schoolchildren are now 3 in. taller and 2 lb heavier than at the previous survey 10 years earlier? Because of this the heights and weights of sixty childreno 
between the ages of 5 and 14 years admitted to hospital within one month of the onset of a first attack of rheumatic fever were analysed in the same way. Only two of these showed weights more than 10 per cent. below the standard as defined above, and none showed height or weight more than 10 per cent. above standard. It was therefore felt that a deviation of 10 per cent. from this standard could be taken as abnormal.

The points noted in the radiographs were the presence of prematurity or retardation in epiphyseal development, the state of epiphyseal fusion, and metaphyseal growth lines and growth defects, as well as abnormal periosteal growth and erosions due directly to the disease. Skeletal maturity estimations were all made by one of us (B.A.) by reference to the standards of Greulich and Pyle (1950). Each radiograph was assessed blind (only the sex of the child being known) and, on two separate occasions, the interval between readings varying from 6 to 12 weeks. Firstly the development of the epiphyses as a whole was judged to be equal to, in advance of, or behind the standard by one year and changes in single epiphyses were then examined more closely. The figures obtained were later compared and correlated with the actual age of the child. In only two out of 449 radiographs was there a marked discrepancy between the separate readings. Mainland (1953), discussing the use of skeletal age as a means of estimating development, suggested that there was considerable systematic and variable error. The probable reason for our apparently smaller variable error is due to the fact that we did not attempt to estimate the small changes occurring in periods of less than one year. No estimate of systematic error was made. All the radiographs were reviewed by both of us to minimize errors in the assessment of abnormalities due to the disease process.

Correlation was made with the presence of disease activity as judged by clinical signs and with an erythrocyte sedimentation rate raised above an upper limit of $15 \mathrm{~mm}$./hr (Westergren) at the time of assessment.

\section{Results}

(1) Growth as Weight (Table I).-No child was more than 10 per cent. above standard weight when first seen and only four out of a total of 76 treated conservatively became so during the period of observation. Each of these four children had shown no disease activity for at least one year before the overweight measurement. Conversely, loss of weight early in the disease was common; 21 out of 53 were more than 10 per cent. below the standard when first seen within one year of the onset. Weight rose with recovery, and, in many instances, particularly where the disease was of fairly short duration (1-3 yrs), it returned to normal. The minimum weight recorded was 50 per cent. of the standard normal, but in the majority of cases it was between 60 and 70 per cent. of normal in the 5 to 14 age group and between 70 and 80 per cent. in the under 5 group.

TABLE I

CORRELATION OF WEIGHT DEFECT WITH DURATION
AND ACTIVITY OF DISEASE IN CHILDREN ON CONSERVATIVE THERAPY*

\begin{tabular}{|c|c|c|c|c|c|}
\hline \multirow{3}{*}{$\begin{array}{l}\text { Time } \\
\text { since } \\
\text { Onset } \\
\text { (yrs) }\end{array}$} & \multicolumn{4}{|c|}{$\begin{array}{l}\text { Proportion of Patients more than } \\
10 \text { per cent. below Normal }\end{array}$} & \multirow{3}{*}{$\begin{array}{c}\text { Total } \\
\text { Number } \\
\text { in } \\
\text { One Year }\end{array}$} \\
\hline & \multicolumn{2}{|c|}{$\begin{array}{c}\text { Under } 5 \text { years old } \\
\text { at Onset } \\
\text { (42 cases) }\end{array}$} & \multicolumn{2}{|c|}{$\begin{array}{c}\text { Between } 5 \text { and } 14 \\
\text { years old at Onset } \\
\text { (59 cases) }\end{array}$} & \\
\hline & Active & Inactive & Active & Inactive & \\
\hline $0-1$ & $7 / 19$ & $0 / 0$ & $14 / 34$ & $0 / 0$ & 53 \\
\hline $1-2$ & $6 / 10$ & $1 / 6$ & $12 / 20$ & $2 / 6$ & 42 \\
\hline $2-3$ & $1 / 2$ & $3 / 12$ & $10 / 14$ & $2 / 10$ & 38 \\
\hline $3-4$ & $4 / 9$ & $0 / 7$ & $10 / 13$ & $0 / 5$ & 32 \\
\hline $4-5$ & $3 / 5$ & $3 / 7$ & $3 / 4$ & $1 / 3$ & 19 \\
\hline $5-10$ & $8 / 10$ & $2 / 7$ & $11 / 11$ & $1 / 5$ & 33 \\
\hline
\end{tabular}

* Each case figures once only in each year-since-onset group, but only 53 of a total of 101 cases furnished readings for the first year. There was a total of 217 readings for the 101 cases.

(2) Growth as Height (Table II).--It can be seen that height is much less frequently affected than weight. Here again duration of activity appeared to be an important factor in the production of this defect, since when the disease became inactive the height returned to normal in the course of 2 to 3 years

TABLE II

CORRELATION OF HEIGHT DEFECT WITH DURATION AND ACTIVITY OF DISEASE IN CHILDREN ON CONSERVATIVE THERAPY*

\begin{tabular}{|c|c|c|c|c|c|}
\hline \multirow{3}{*}{$\begin{array}{l}\text { Time } \\
\text { since } \\
\text { Onset } \\
\text { (yrs) }\end{array}$} & \multicolumn{4}{|c|}{$\begin{array}{l}\text { Proportion of Patients more than } \\
10 \text { per cent. below Normal }\end{array}$} & \multirow{3}{*}{$\begin{array}{c}\text { Total } \\
\text { Number } \\
\text { in } \\
\text { One Year }\end{array}$} \\
\hline & \multicolumn{2}{|c|}{$\begin{array}{c}\text { Under } 5 \text { years old } \\
\text { at Onset } \\
\text { (42 cases) }\end{array}$} & \multicolumn{2}{|c|}{$\begin{array}{l}\text { Between } 5 \text { and } 14 \\
\text { years old at Onset } \\
\text { ( } 59 \text { cases) }\end{array}$} & \\
\hline & Active & Inactive & Active & Inactive & \\
\hline $0-1$ & $3 / 17$ & $0 / 0$ & $0 / 29$ & $0 / 0$ & 46 \\
\hline $1-2$ & $2 / 11$ & $0 / 6$ & $2 / 13$ & $0 / 9$ & 39 \\
\hline $2-3$ & $0 / 3$ & $1 / 11$ & $3 / 10$ & $0 / 10$ & 34 \\
\hline $3-4$ & $1 / 7$ & $0 / 8$ & $1 / 7$ & $0 / 7$ & 29 \\
\hline 4-5 & $1 / 5$ & $0 / 7$ & $0 / 2$ & $0 / 3$ & 17 \\
\hline $5-10$ & $3 / 9$ & $0 / 7$ & $4 / 7$ & $1 / 2$ & 25 \\
\hline
\end{tabular}

* Each case figures once only in each year-since-onset group, but only 46 of a total of 94 cases furnished readings for the first year. There was a total of 190 readings for the 94 cases. 

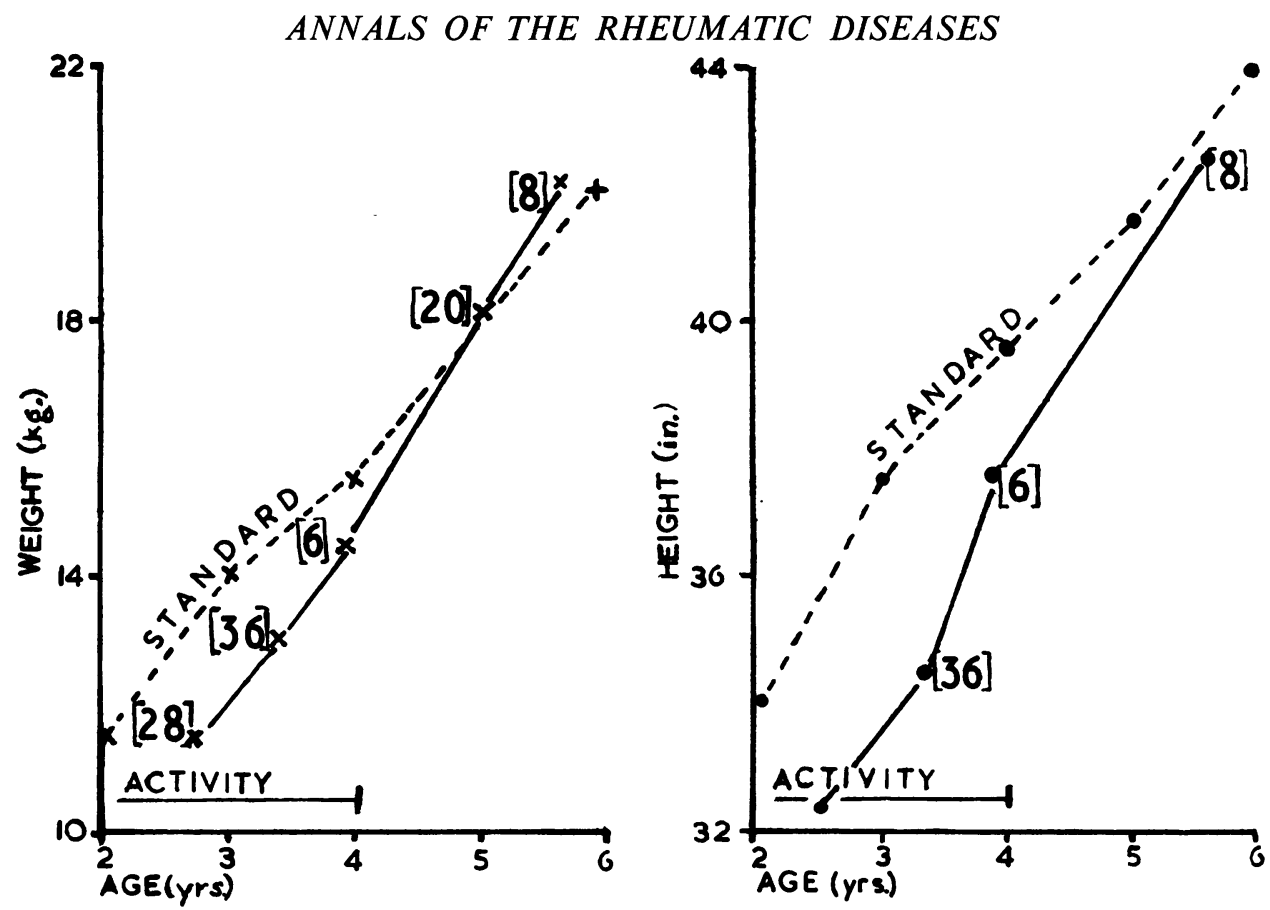

Fig. 2.-Height and weight of a girl with rheumatoid arthritis starting at $1 \frac{1}{2}$ years of age compared with a standard curve. As the activity of the disease regressed (see erythrocyte sedimentation rate figures at each point) both height and weight rose towards normal.

provided there had been no premature fusion of epiphyses (Fig. 2). The minimum height recorded in this series was 80 per cent. of normal; those patients in which this defect persisted as the disease became inactive were of very long standing and had had the disease severely. As we did not include the height data of those seriously affected children in whom there were flexion deformities of the hips and knees, these results are perhaps less striking than they otherwise might be, since these are the cases most likely to have defective bone growth. That severe disease alone can produce height defect is shown in Fig. 3 (opposite), and that this is more pronounced when there is much resultant joint deformity is shown in Fig. 4 (opposite).

\section{(3) $X$-Ray Analysis}

(a) Epiphyseal Development and Fusion.-In Group I (with no involvement of the wrist at any time) there were eight patients under 5 years of age: a total of 27 radiographs of the hands and wrists covering the first 10 years of the disease were studied (the odd number is due to a patient with one normal and one affected wrist). In one case, both wrists showed a general retardation of the carpal epiphyses. In four cases there was retardation of a single epiphysis, the ulnar styloid (bilateral in three); in two of these this was followed by advancement of this epiphysis when the disease became quiescent, the others all remaining normal for the age. Growthô lines were present in the radius in seven $x$ rays of four cases and these four were the same who hade shown the growth abnormality of the ulna.

In the 5 to 14-year age group, a total of 66 radiographs of eighteen cases with neither wrist involved and four cases with only one normal wrist were examined. In six cases (fourteen radiographs) retardation of development affected more than one epiphysis. In four of these cases showing general retardation the other wrist was clinically severely affected, but its development was normal or in advance of the age. Growth lines were observed in 21 of the 66 normal radiographs and involved nine cases ( 50 per cent.), three of these showing no retardation of epiphyseal development.

To compare the effect of another long-continued illness on skeletal development, hands and wrists were analysed from nine children between the ages of 3 and 14 years who were suffering from rheumatic fever, which had been continuously active for at least 6 months before the $x$ ray was taken. In twelve of the radiographs (both hands of six patients), growth lines were present. Only one showed a year's retardation, involving a single epiphysis (ulnar).

In Group II (patients who had shown wrist involvement for less than 3 months) a total of six cases under 5 years (sixteen radiographs), and seven 


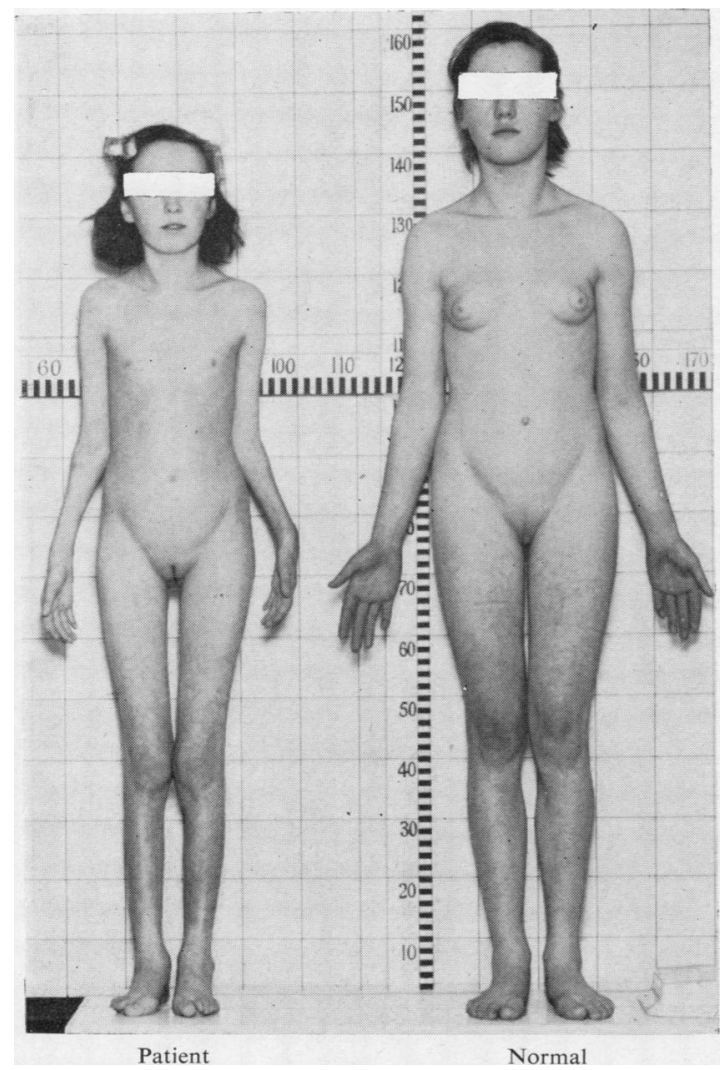

Fig. 3.-Twin sisters aged 14, one normal (height $61 \frac{1}{2}$ in., weight $47 \cdot 2 \mathrm{~kg}$.) and one after 5 years of moderately active rheumatoid arthritis (height $55 \frac{1}{2}$ in., weight $26.8 \mathrm{~kg}$.).

patients between 5 and 14 years (thirty radiographs) were examined over the 10-year period following the onset of the disease. In the under 5-year age group, two cases (six radiographs) showed general sub-normal development, two other cases (four radiographs) had growth lines, and one case (two radiographs) had abnormal periosteal elevation. In the older age group, three patients (seven radiographs) showed retarded development, and in one case both wrists showed advancement of ulnar epiphyseal growth. Four cases (seven radiographs) showed growth lines: three having retarded development, and the fourth growth lines on one side and abnormal periosteal accretion on the other.

As was expected, the majority of changes occurred in Group III (i.e. in those cases in which wrist involvement continued for more than 3 months). A total of 31 (129 radiographs) of the under-5s and 49 (181 radiographs) in the 5 to $14 \mathrm{~s}$ were reviewed. In the under-5s (Table III, overleaf), a tendency to acceleration of epiphyseal development was noted

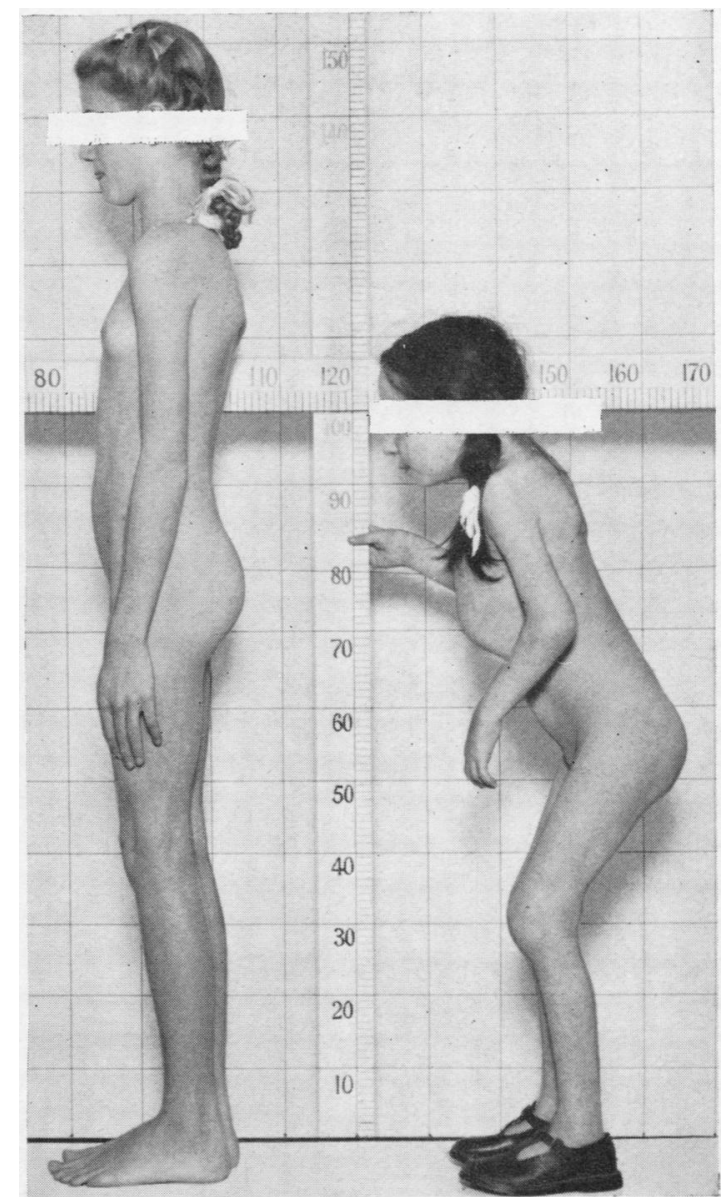

Fig. 4.-Two children aged 11 years, one normal and one with rheumatoid arthritis of 5 years' duration showing severe deformities as well as stunting.

in fifteen cases (37 radiographs), while ten cases (29 radiographs) showed retardation and three cases (five radiographs) showed a mixture of retardation and acceleration. As might be expected, premature epiphyseal fusion was rare early, but tended to occur later, causing growth defects particularly after 4 years of illness. This decrease usually affected the ulna and occasionally the metacarpal bones.

In the 5 to 14-year age group (Table III, overleaf) acceleration of epiphyseal development occurred in fourteen cases (32 radiographs), retardation in eighteen cases ( 37 radiographs), and a mixture of the two in two cases (three radiographs). The tendency to premature epiphyseal fusion occurred earlier in the course of the disease as the age of the patient increased, so that this was noted even as early as the second year of the illness. Premature fusion may also occur in involved joints in an affected 
TABLE III

ANALYSIS OF 312 RADIOGRAPHS OF HANDS AND WRISTS OF EIGHTY CASES WITH BILATERAL INVOLVEMENT FOR MORE THAN 3 MONTHS, SEEN BETWEEN 0 AND 10 YEARS SINCE ONSET OF DISEASE

Number and Type of Cases in which Abnormalities were seen

\begin{tabular}{|c|c|c|c|c|c|c|}
\hline \multicolumn{3}{|c|}{ Age at Onset (yrs) $\quad}$. & \multicolumn{2}{|c|}{$0-5$} & \multicolumn{2}{|c|}{$5-14$} \\
\hline \multicolumn{3}{|c|}{ Total Number of Cases } & \multicolumn{2}{|c|}{31} & \multicolumn{2}{|c|}{49} \\
\hline Side $\quad$. & . & - & Right & Left & Right & Left \\
\hline \multirow{4}{*}{$\begin{array}{l}\text { Epiphyseal } \\
\text { and Carpal } \\
\text { Development }\end{array}$} & Normal & & 5 & 6 & 21 & 21 \\
\hline & Advanced & & 14 & 15 & 14 & 14 \\
\hline & Retarded & & 10 & 9 & 13 & 12 \\
\hline & Mixed & & 2 & 3 & 1 & 2 \\
\hline \multicolumn{3}{|c|}{ Premature Epiphyseal Fusion } & 3 & 2 & 15 & 17 \\
\hline \multicolumn{3}{|l|}{ Growth Defects } & 9 & 10 & 17 & 18 \\
\hline Growth Lines .. & . & . & 23 & 24 & 26 & 25 \\
\hline Periostitis & $\cdots$ & . & 17 & 16 & 15 & 19 \\
\hline Erosions & . & . & 18 & 18 & 32 & 30 \\
\hline
\end{tabular}

hand; Fig. 5 shows a case with severe involvement of one carpus and wrist only, in which the epiphyses of all terminal phalanges fused more than 2 years before the uninvolved side.

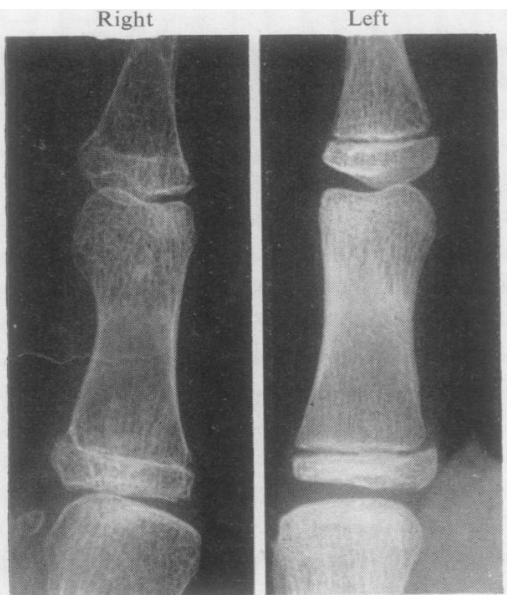

Fig. 5.-Radiographs showing epiphyseal fusion in un af fected thumb joints on the side of a right wrist affected for 3 years, compared with the thumb of the contra-lateral normal hand in a boy aged 16 .

(b) Growth Defects.*-Because of the tendency to premature fusion, growth defects occurred earlier and more frequently in the older than in the younger patients. Eighteen cases showing defects were noted in the older age group (5-14 years at onset), being unilateral in six (38 radiographs); the younger group ( $0-5$ years at onset) included ten cases showing defects. Most of these occurred in the ulna and the 4th and 5th metacarpal bones, although occasionally the phalanges were affected (Fig. 6). Despite the many growth defects seen radiologically, obvious clinical deformities (such as that seen in Fig. 7) were rare, occurring in only five children.

* Deficiency in linear growth of bones compared with opposite or neighbouring bones.

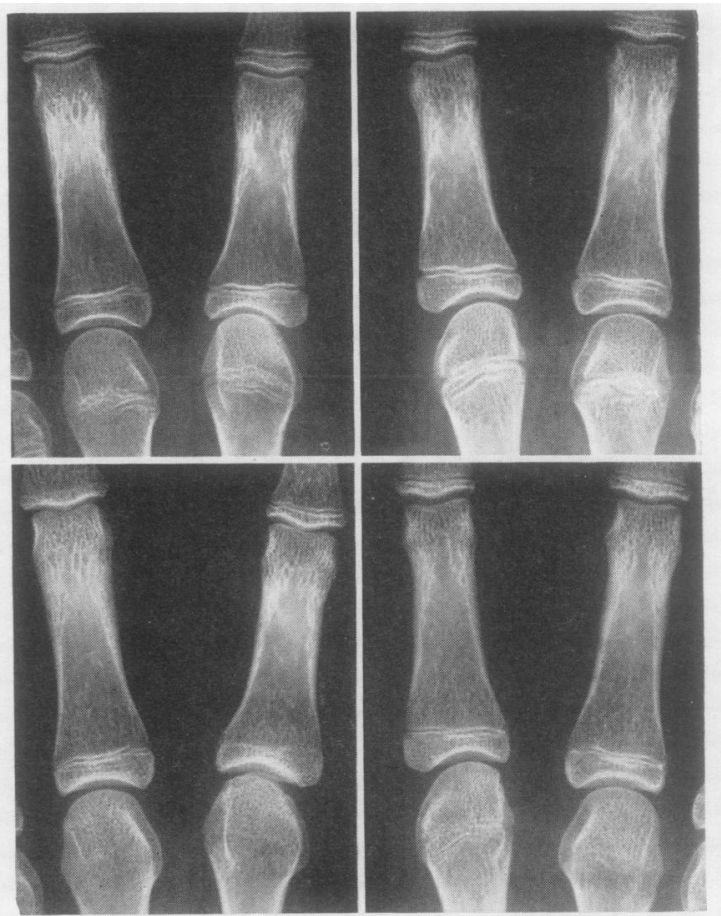

Fig. 6.-Premature fusion of epiphyses in the neighbourhood of thg $\vec{\theta}$ involved second right metacarpal and third right proximal intexo 0 phalangeal joints at 14 and 28 months, in a boy who was 14 years ol at the onset of disease. The right second metacarpal grew $1 \mathrm{~mm}$ in this period and the left grew $3 \mathrm{~mm}$.

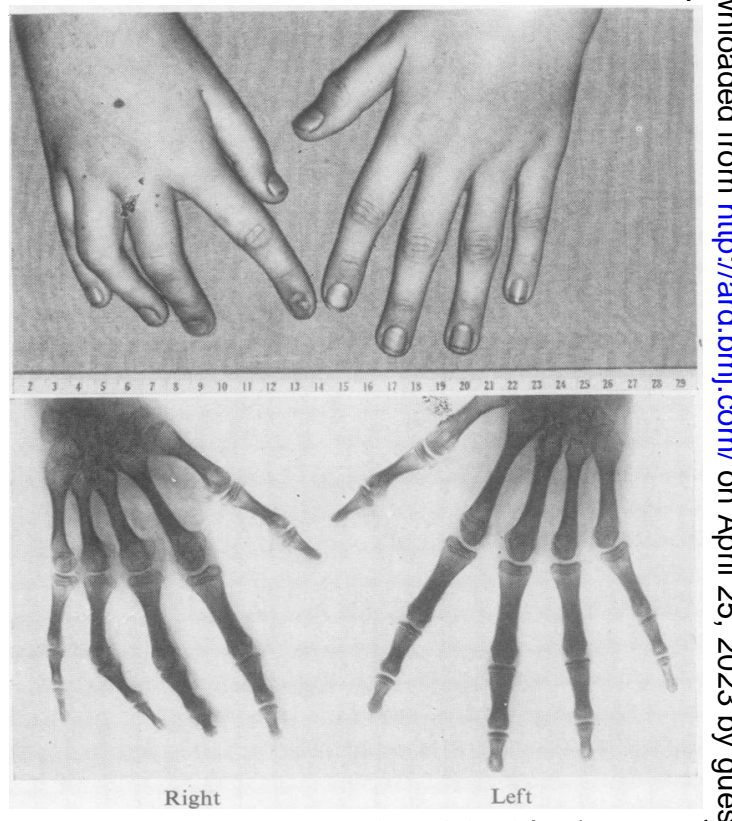

Fig. 7. -16 per cent. shortening of right third and fourth metacarpal $\stackrel{\mathscr{S}}{+}$ bones in a girl aged 13 who had had rheumatoid arthritis for 111 years. 

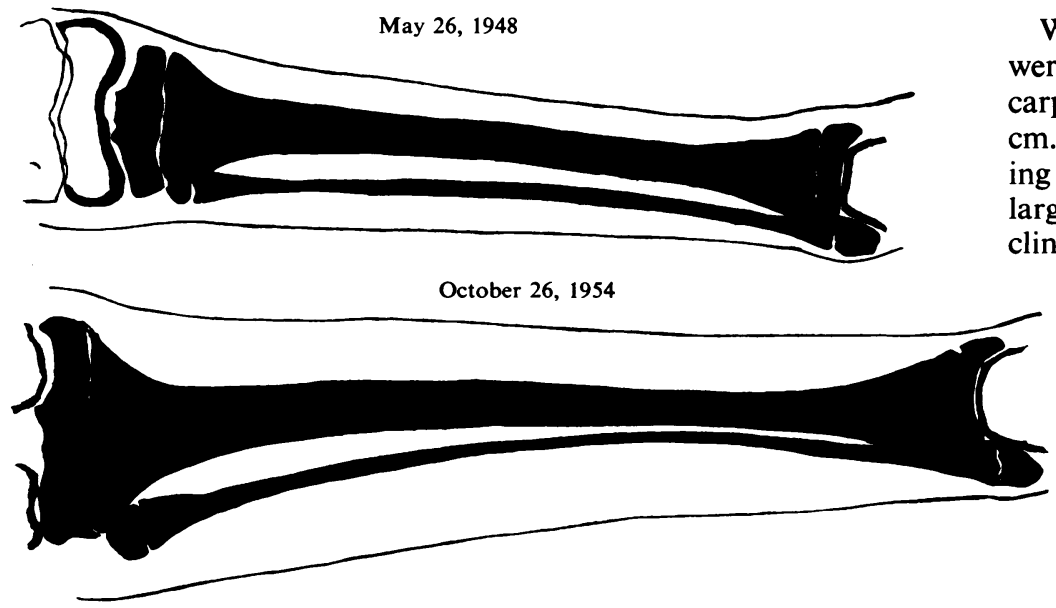

Fig. 8.-Rheumatoid arthritis involving the knee joint, starting at the age of $5 \frac{3}{4}$ years; $x$-ray tracing shows increased bowing of the fibula between the ages of 7 and 13 years.

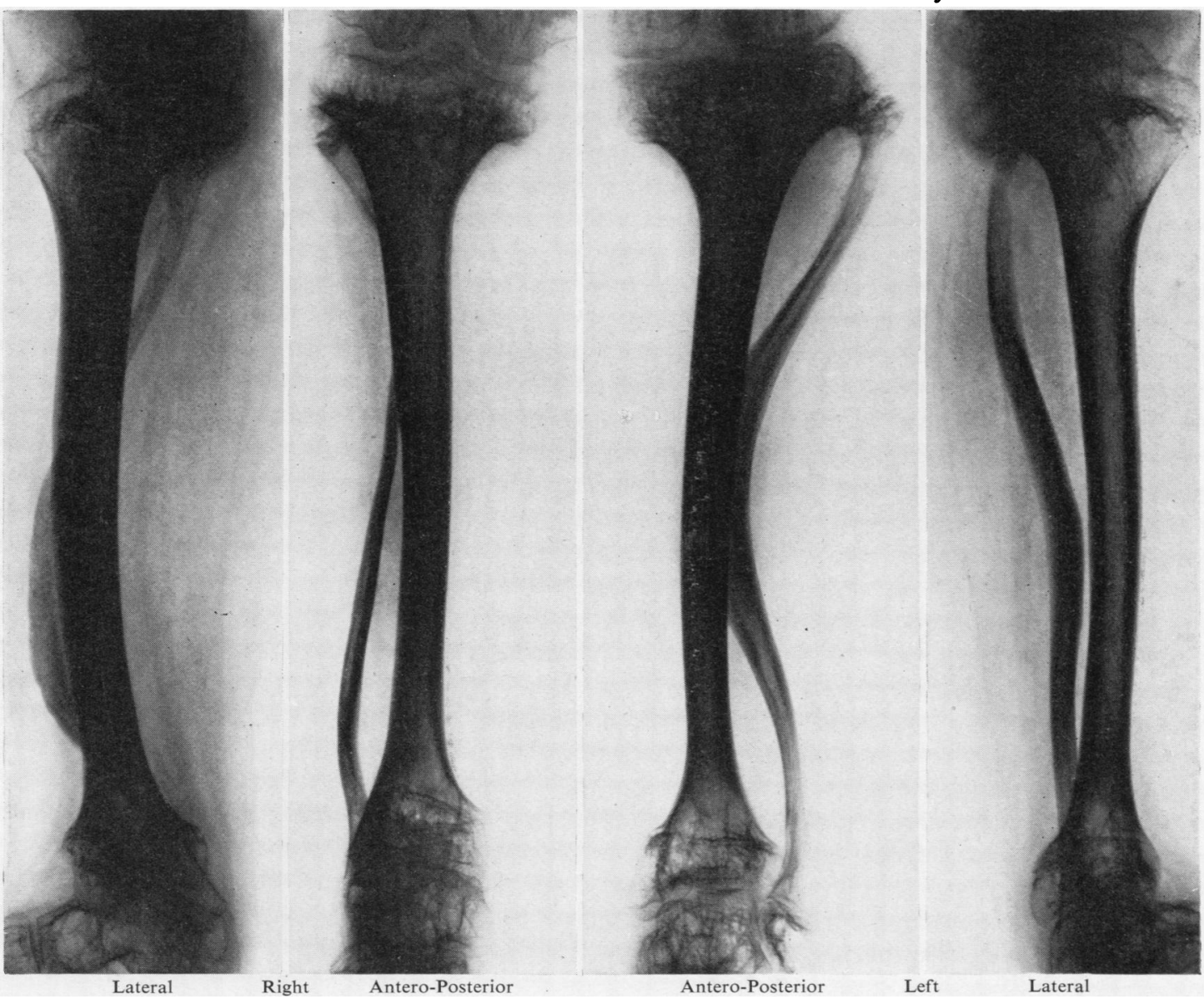

Where unilateral growth defects were present, the affected metacarpal was between 0.4 and $1 \cdot 3$ $\mathrm{cm}$. shorter than the corresponding healthy one, but only the larger defects were obvious on clinical inspection. In the forearms and legs where two bones may be differentially affected by growth disturbances, gross deformities may sometimes occur. Recognition of this in the early stages (Fig. 8) is important from the point of view of orthopaedic management, since the gross deformities seen in Fig. 9 may thus be avoidable.

the age of $1 \frac{1}{2}$ years. Lateral and antero-posterior radiographs show the fibula bowing in relation to the epiphyseal development of the tibia at the involved knee and ankle joints. 
The very minor degrees of growth inhibition mani- veloped in the epiphyses as well as in the metaphyses, fest as growth lines were often pronounced. These de- producing a double-contoured effect (Fig. 10).

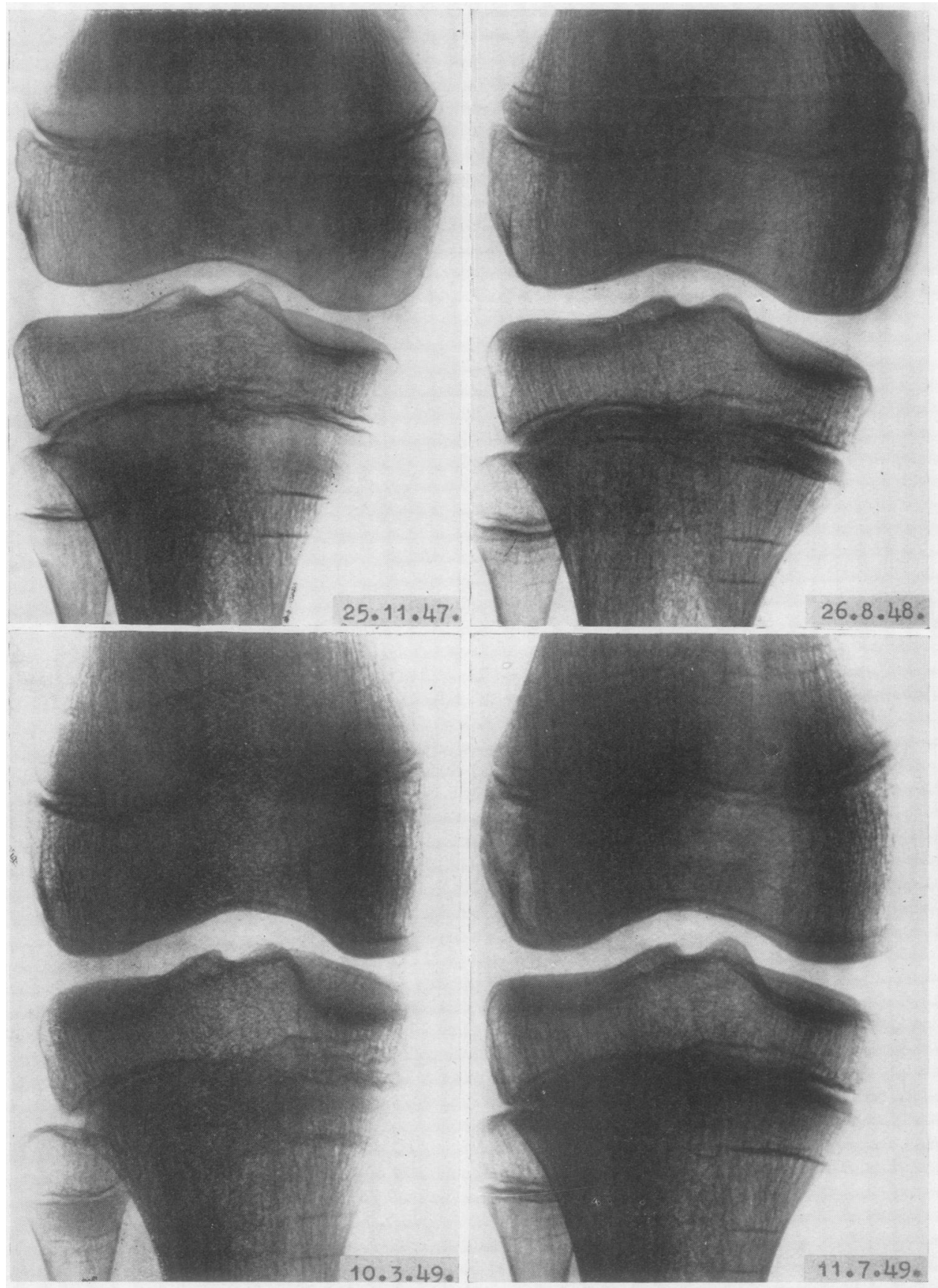

Fig. 10.-Development of double contours round femoral and tibial epiphyses over a period of $1 \frac{1}{2}$ years in a boy bedridden for 3 years from the onset of the disease at the age of $8 \frac{1}{2}$ years. This is due to dense recalcification of rarefied areas seen in the first $x$ ray, at the age of 12 , after mobilization, resulting in the metaphysis in a dense growth line well seen in the last two $x$ rays. 
Histologically this is seen to be produced by a well-marked transverse bony layer separated from subchondral bone (Fig. 11).

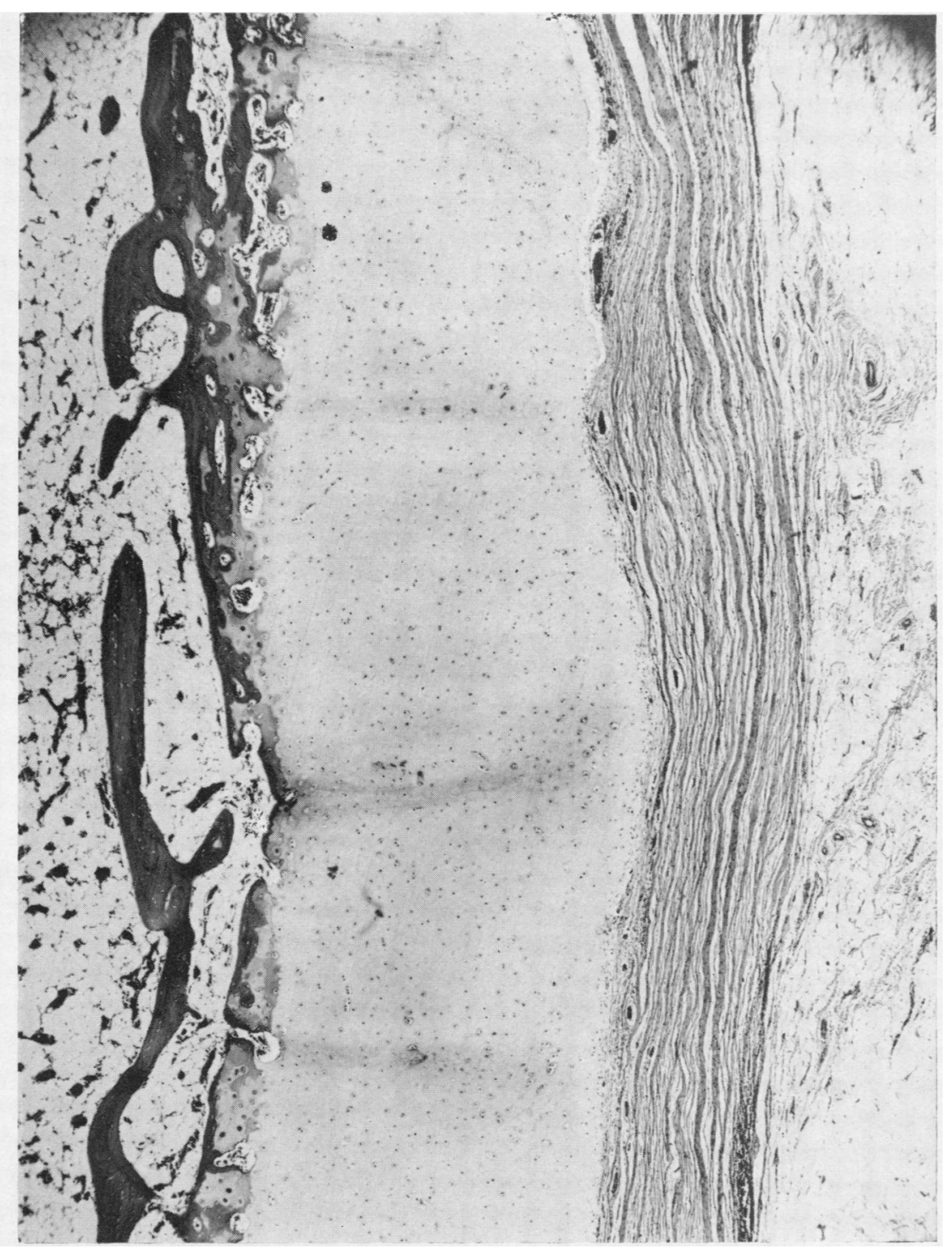

Fig. 11.-Photomicrograph of the femoral condyle (haematoxylin and eosin $\times 25$ ) in girl aged 13 , showing surface pannus and doublecontoured bone lines. 

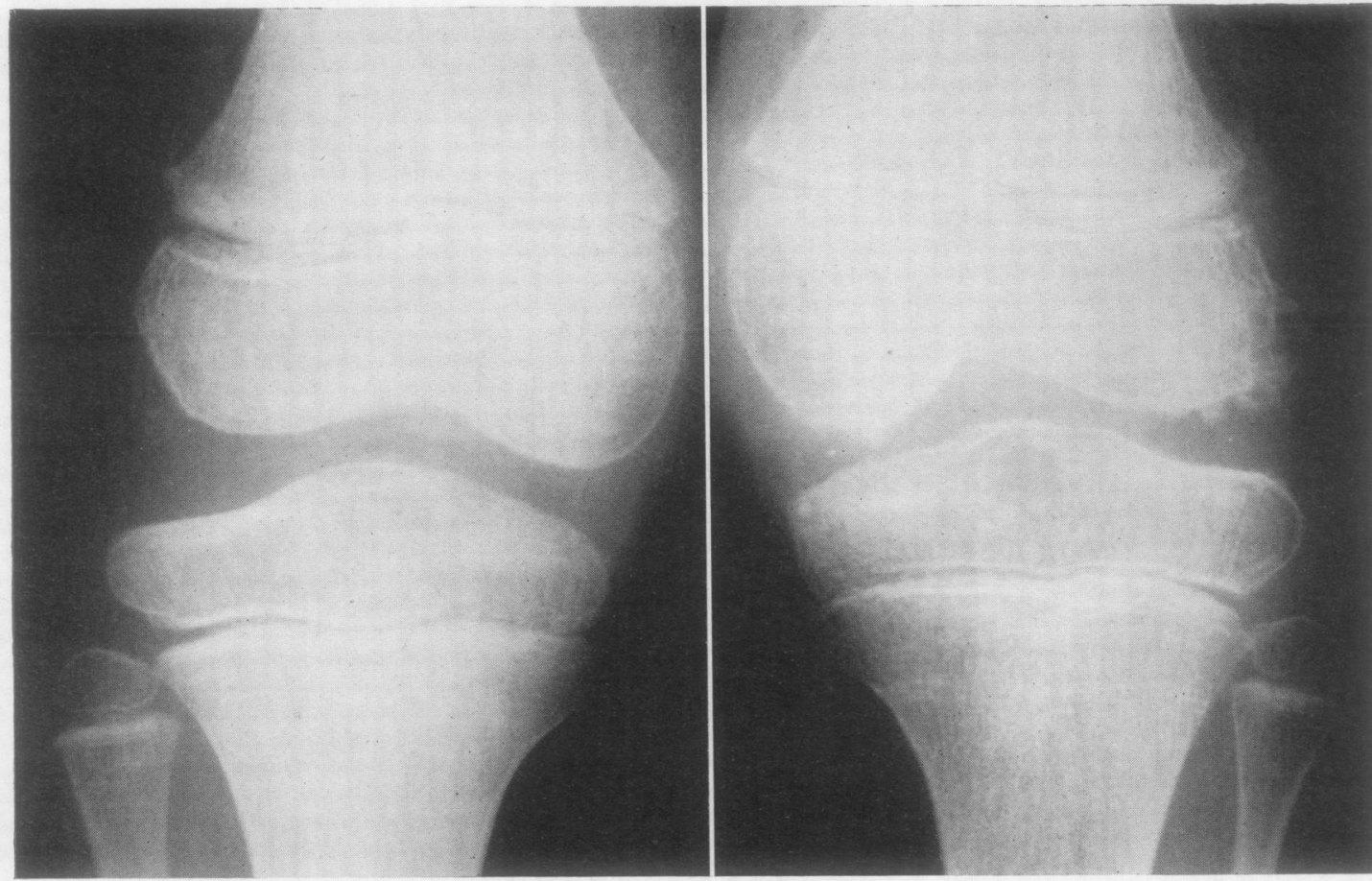

Fig. 12._-"Woolly" subchondral bony outgrowths developing in the affected knee compared with the normal side in a boy aged 8.1 at the onset of rheumatoid arthritis. Radiographs taken 18 months after onset.

This did not seem to be related to the woolly subchondral bony outgrowths seen at early ages, which are more pronounced in Still's disease and on the affected side (Fig. 12).

The latter is due to irregular outgrowths of vessels into cartilage and subsequent ossification (Fig. 13).

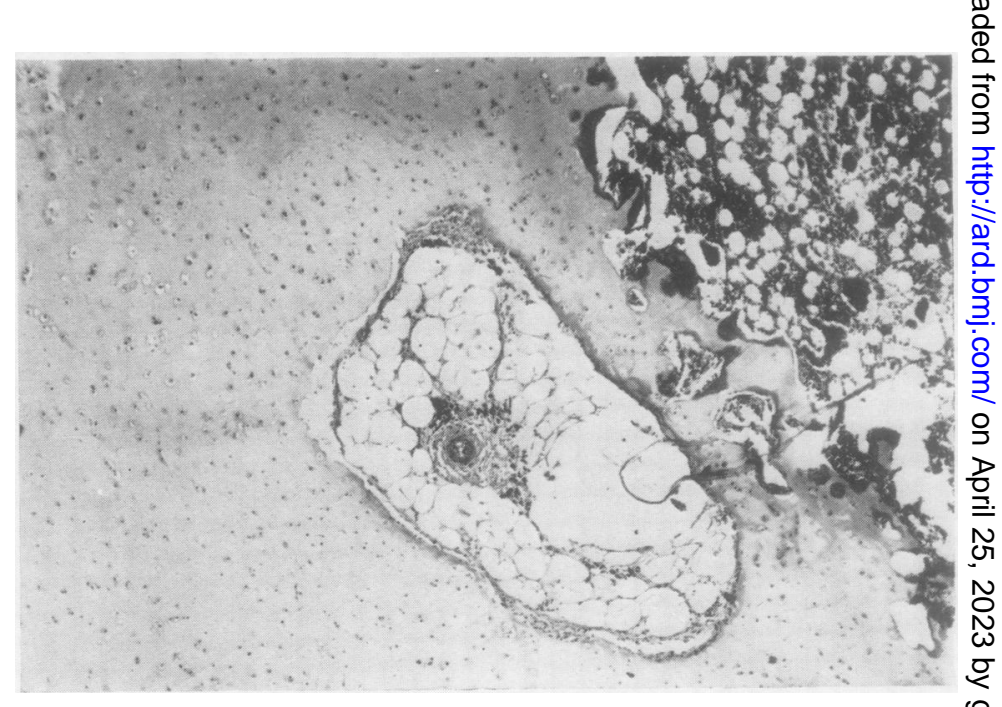

Fig. 13.-Photomicrograph (haematoxylin and eosin $\times 40$ ) showing vascular outgrowths $\frac{\mathrm{C}}{\mathrm{C}}$ from the lower femoral epiphysis in a child aged $3 \frac{1}{2}$ who had had severe rheumatoid arthritis $\infty$ for $2 \frac{1}{2}$ years, showing slight variable calcification in portions of the periphery. 
Whilst most of the severely affected patients suffered general stunting and showed generalized growth lines, there might be either stimulation or retardation of growth in the neighbourhood of

Unaffected
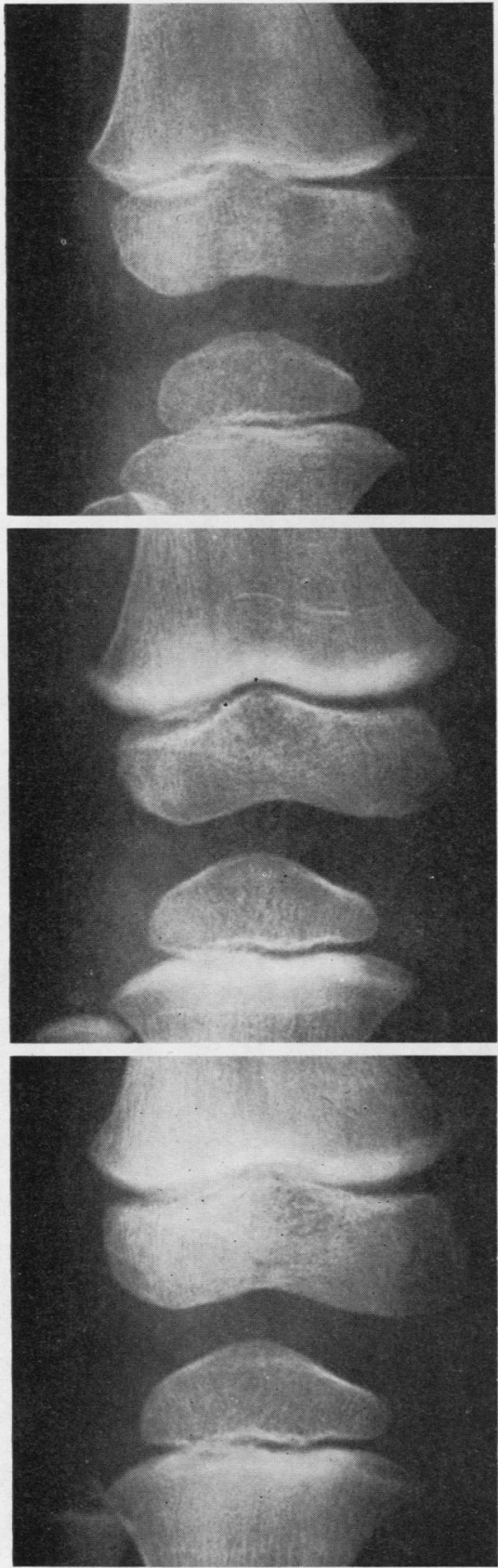

Fig. 14.-Increase in size of the epiphyses over 2 years, to a greater extent in the affected knee than the unaffected, showing dense metaphyseal line more marked on the normal side. inflamed joints. This might affect either epiphyseal or metaphyseal growth. In a child with only one knee joint affected there was a marked increase in epiphyseal size on the affected side (Fig. 14).

Affected

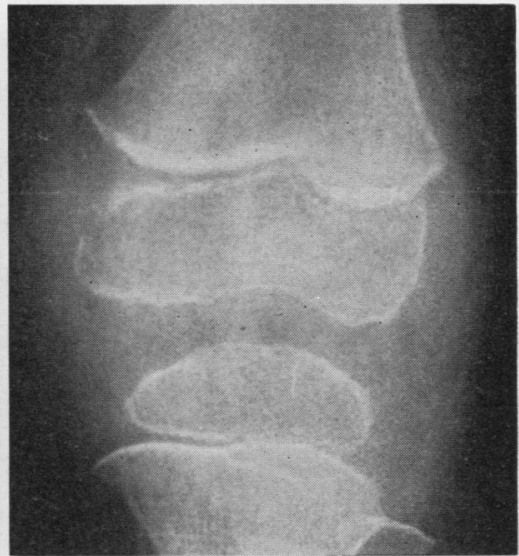

1950

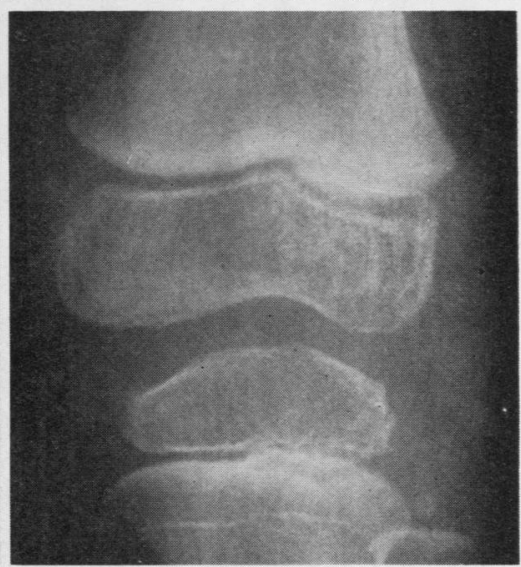

1951

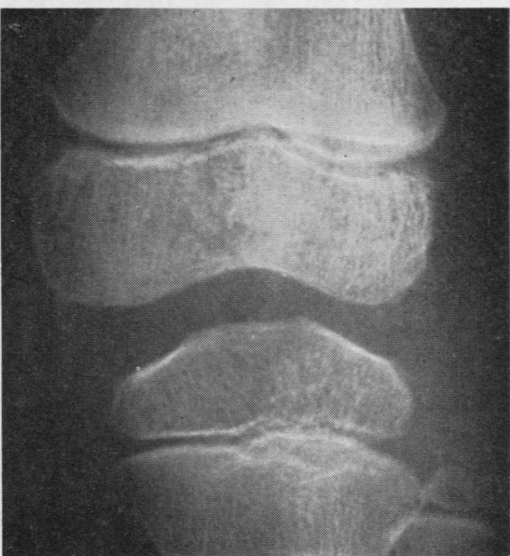

1952 
There were eight cases with unilateral involvement of the knee where assessment of growth was possible by measurement between Harris's lines (in other cases, the lines were not sufficiently distinct to allow certainty of identification). Measured by this means, growth and length of metaphyseal bone was often not affected by local disease (four cases), although there might be thickening due to periosteal accretion: at least one of these had been immobilized. In three instances there was overgrowth on the affected side; in the most severe case there was an increase of 1.9 and $0.5 \mathrm{~cm}$. respectively between the epiphyseal lines of the femur and the tibia over and above the growth on the normal side. In two instances where this was found, it corresponded to a period of immobilization in plaster, and in the third it followed a period of prolonged rest in bed. Unilateral lengthening has been recorded from the time of Paget (1853) as a result of inflammation, and Dennison (1952) has noted it in a haemophiliac haemarthrosis, in tuberculosis of the hip, and in twenty out of eighty cases of osteomyelitis, affecting both of paired bones even if one only were infected. In only one case were the lesions of arrested growth produced by general somatic disturbance closer together on the affected than on the contralateral unaffected bone. The child was at home during this period and not immobilized. As seen in Fig. 15, these bony bands due to arrested metaphyseal growth may contain islets of unaltered cartilage.

(c) Subperiosteal Accretion.-Abnormal subperiosteal bone accretion occurs at all ages early in the

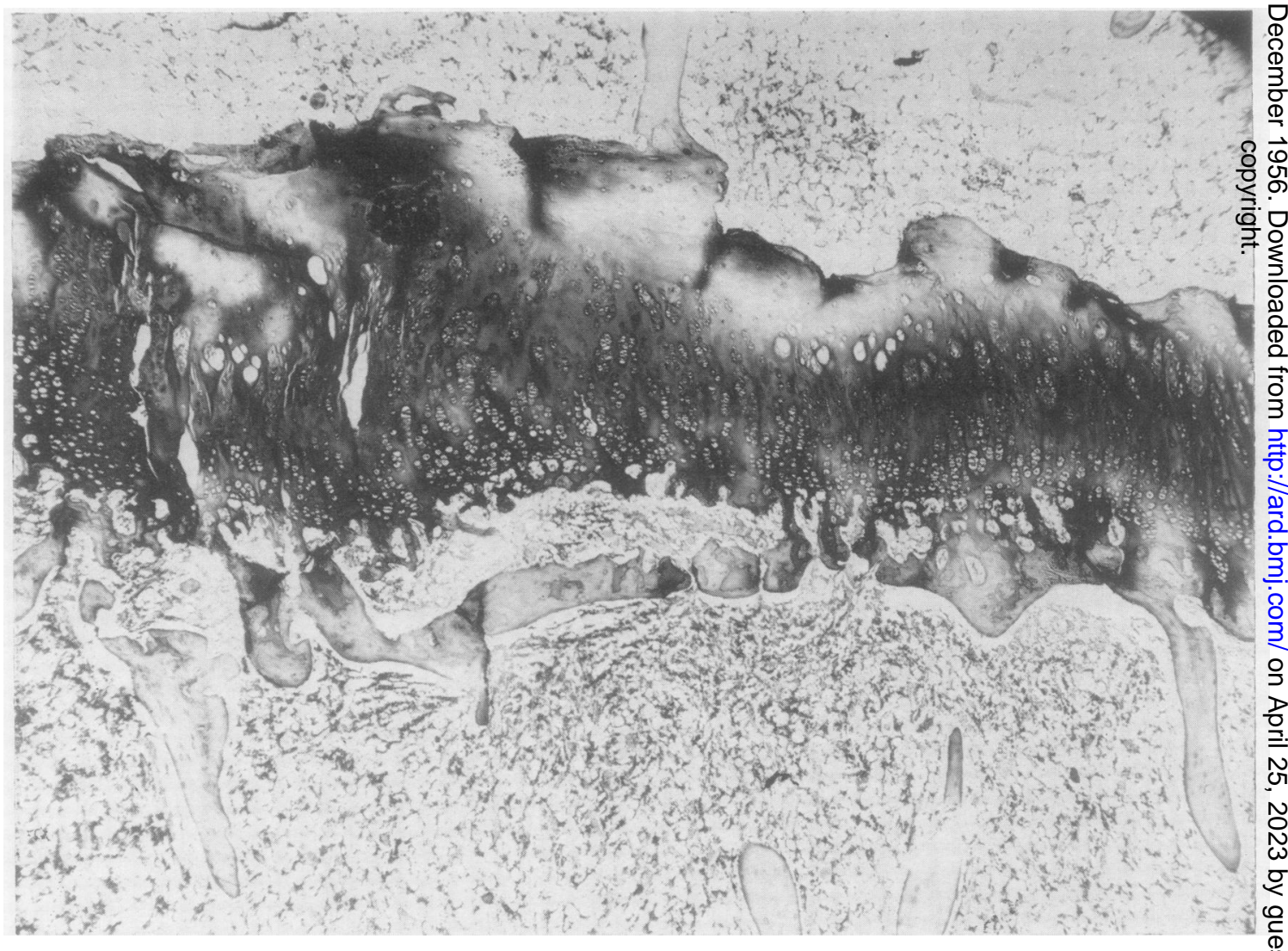

Fig. 15.-Photomicrograph (Leishman $\times 25$ ) of epiphyseal line in a femur in a girl aged 13, showing line of arrested growth with $\stackrel{\mathscr{H}}{+}$ cartilaginous inclusions. 
course of the disease, tending to reabsorb in spite of continued activity of the disease (Fig. 16).

In other cases it blends with the bone and becomes therefore no longer recognizable except in series. This accretion was particularly pronounced in those under 5 years at onset, but it was not more frequent than in the older age group; it occurred in eighteen of the 31 patients under the age of 5 , and in 27 of the 49 patients in whom the disease began after 5 years of age. In the phalanges this produced a curious picture somewhat resembling tuberculous dactylitis, with which it has been confused (Fig. 17). Reabsorption of this new bone seldom proceeds beyond normal, but sometimes subperiosteal absorption may (in the

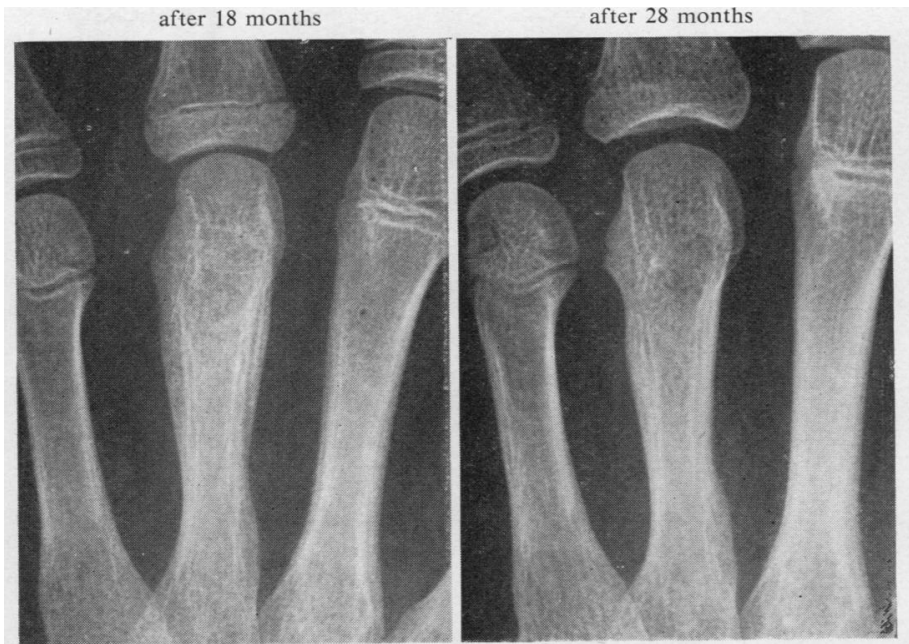

Fig. 16.-Periosteal accretion in neighbourhood of fourth metacarpophalangeal joint with subsidence between the 18 th and 27 th month of the disease in a boy aged 11 at onset. Note premature epiphyseal fusion.

August 6, 1948

December 12,1948

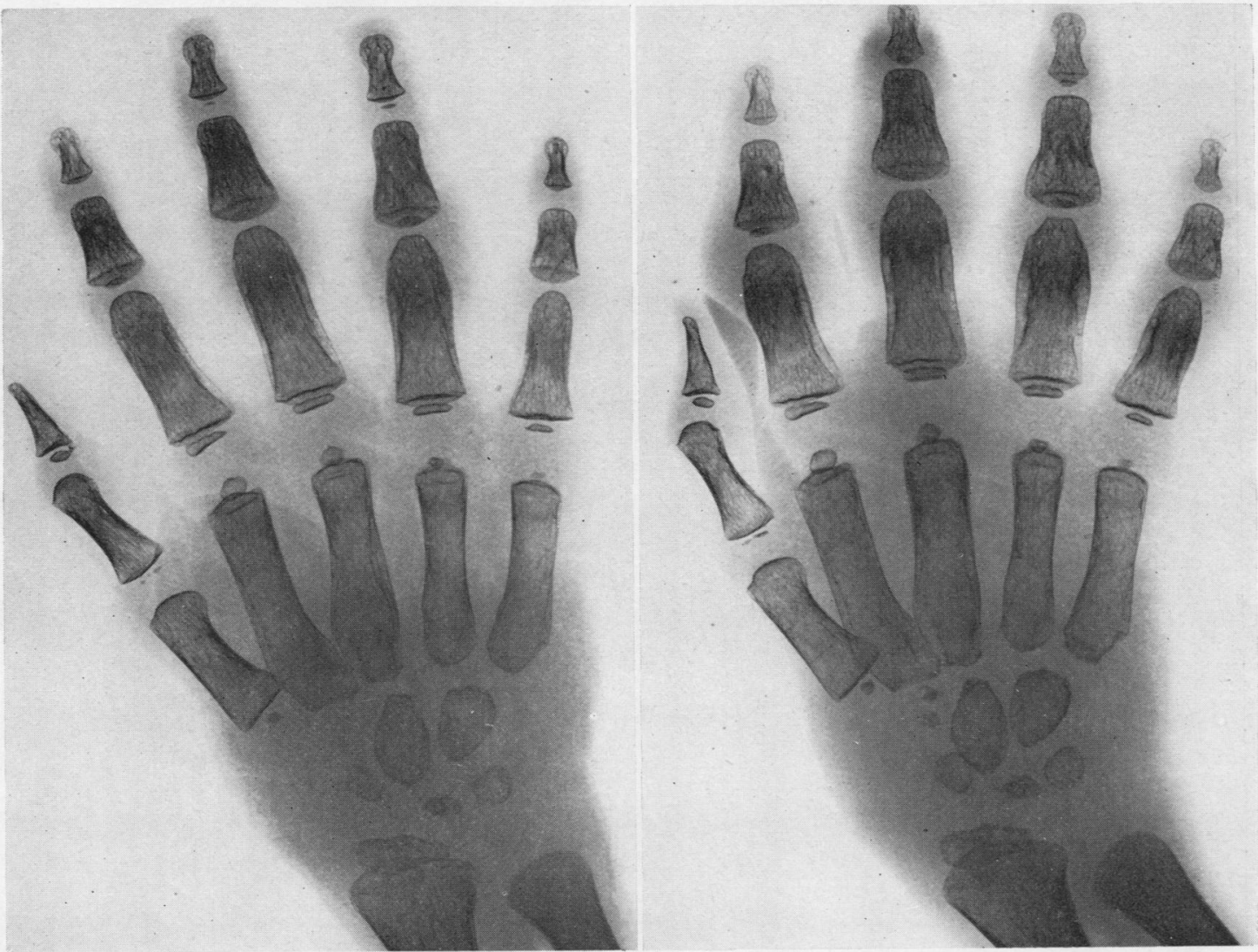

Fig. 17.-Advancement of periosteal accretion in the long bones of the hand, except the thumb, over a period of 4 months in a boy aged $2 \frac{1}{2}$ years who had had rheumatoid arthritis for $1 \frac{1}{5}$ years. 
Fig. 18.- Tubular re-absorption of femur at 1, 2, and 5 years after fracture in a boy aged 10 in whom rheumatoid arthritis had begun one year previously.

absence of function and precipitated by fracture) ly the bony ends forming the terminal inter- $\frac{\mathbb{\Phi}}{\mathbb{\mathbb { Q }}}$ lead to a marked thinning of the bone (Fig. 18). phalangeal joints showed an overgrowth, and this $\frac{3}{0}$ A brief account of the periosteal changes, radio- was also seen to a lesser extent in the proximal $\stackrel{\Phi}{工}$ logical and pathological, has already been presented (Bywaters, 1948) and is to be published in detail. interphalangeal joints, clinically resembling somg- $\vec{\varphi}$ what the nodes developing in old age and know by the names of Heberden and Bouchard respes:

(d) Other Radiological Changes.-Not infrequenttively (Fig. 19). In the stage before the fusion

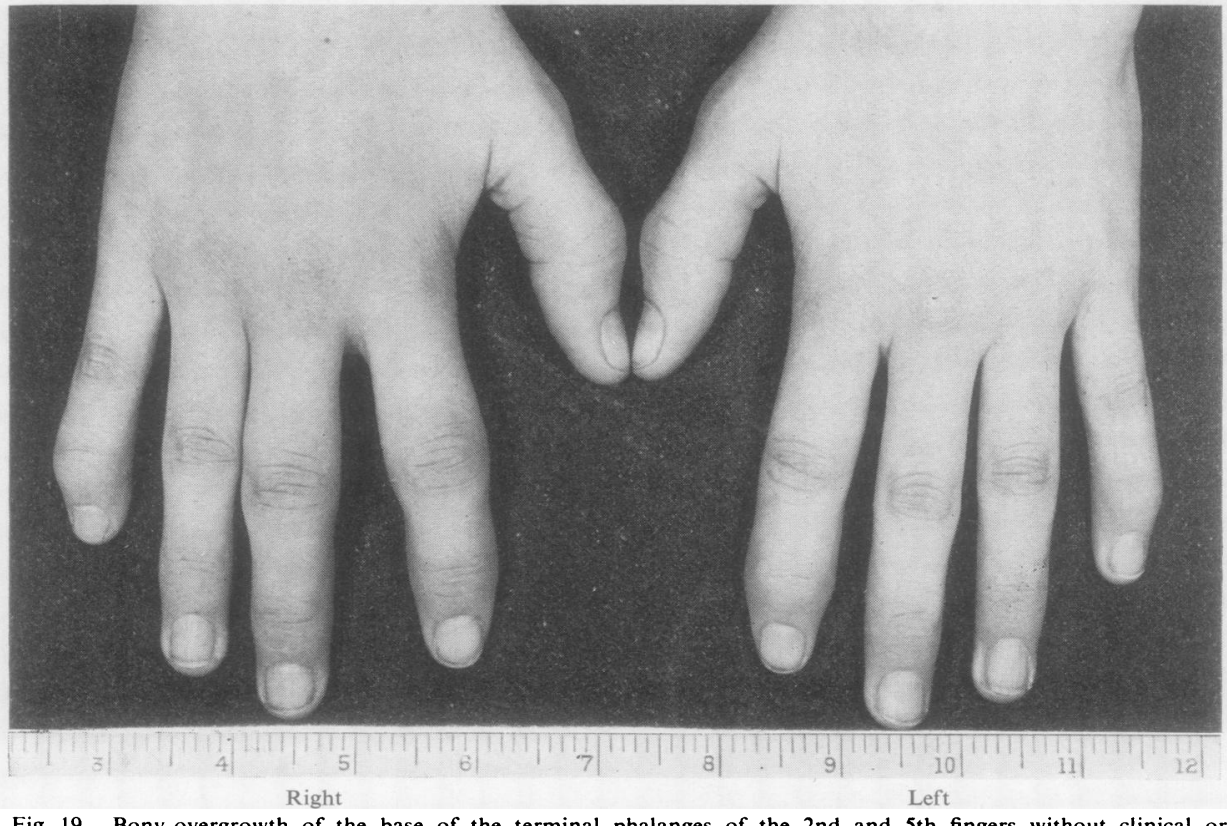


of the epiphyses, the terminal phalanges differed radiologically from those seen in degenerative joint disease, in that no bony outgrowth into the capsular ligament occurred (Fig. 20). This change occurred in seemingly unaffected joints and was due to enlargement and widening of the bony epiphysis; it was often accompanied by the enlargement of the non-growing middle phalangeal head, closely resembling that seen in old age (Fig. 21).

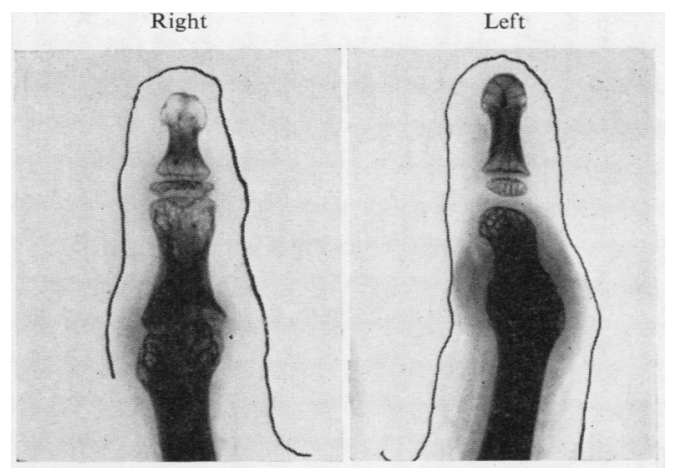

Fig. 20.-Overgrowth of terminal epiphysis clinically somewhat resembling Heberden's node in an affected (right) terminal index joint, compared with the contra-lateral (left) normal finger in a boy aged 12 .
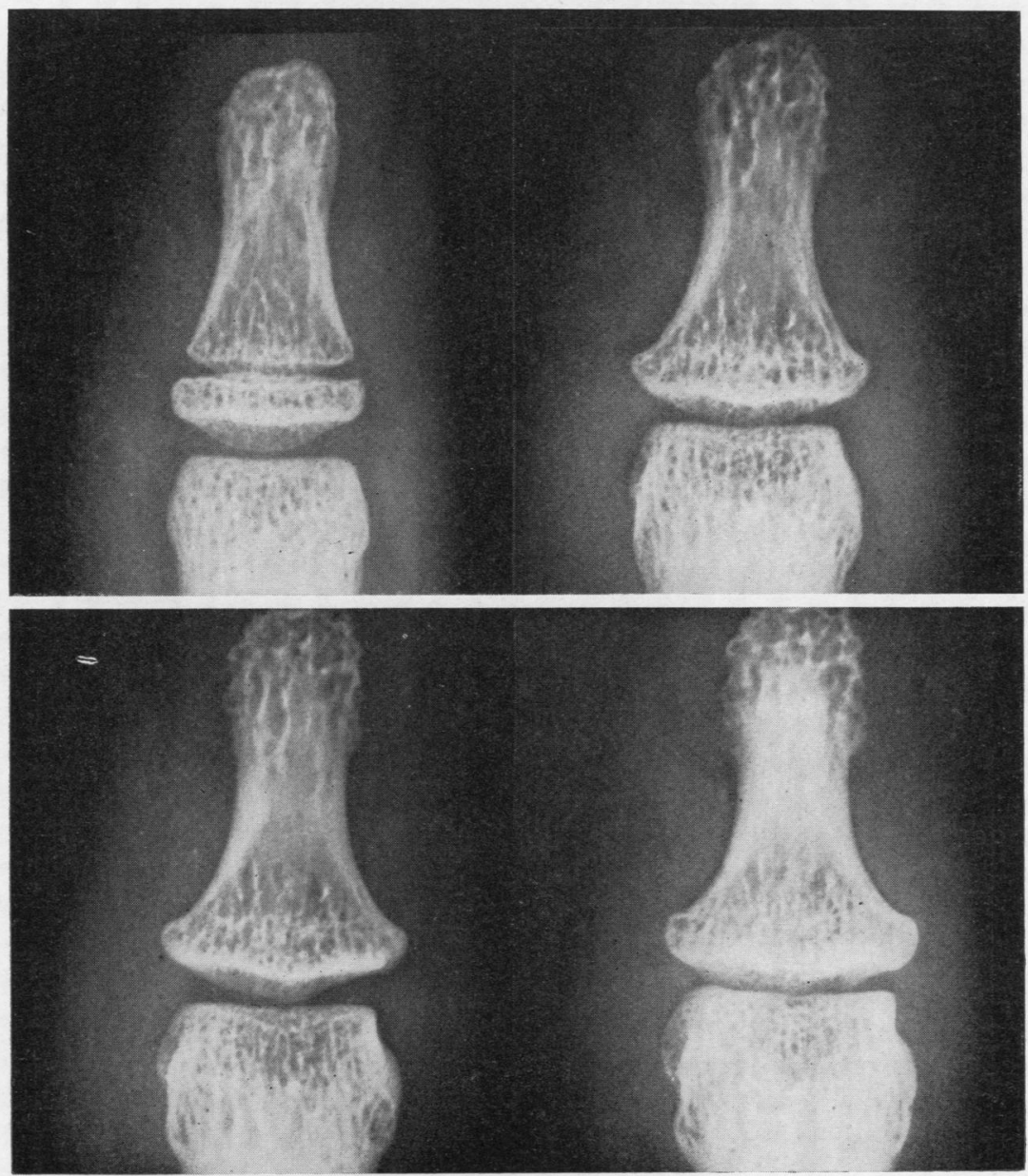

Fig. 21.-Overgrowth of epiphyses of uninvolved termina inter-phalangeal joint, developing over a period of 6 years in a girl aged 13 at onset. Note close similarity of phalangeal head to that of degenerative joint disease. 


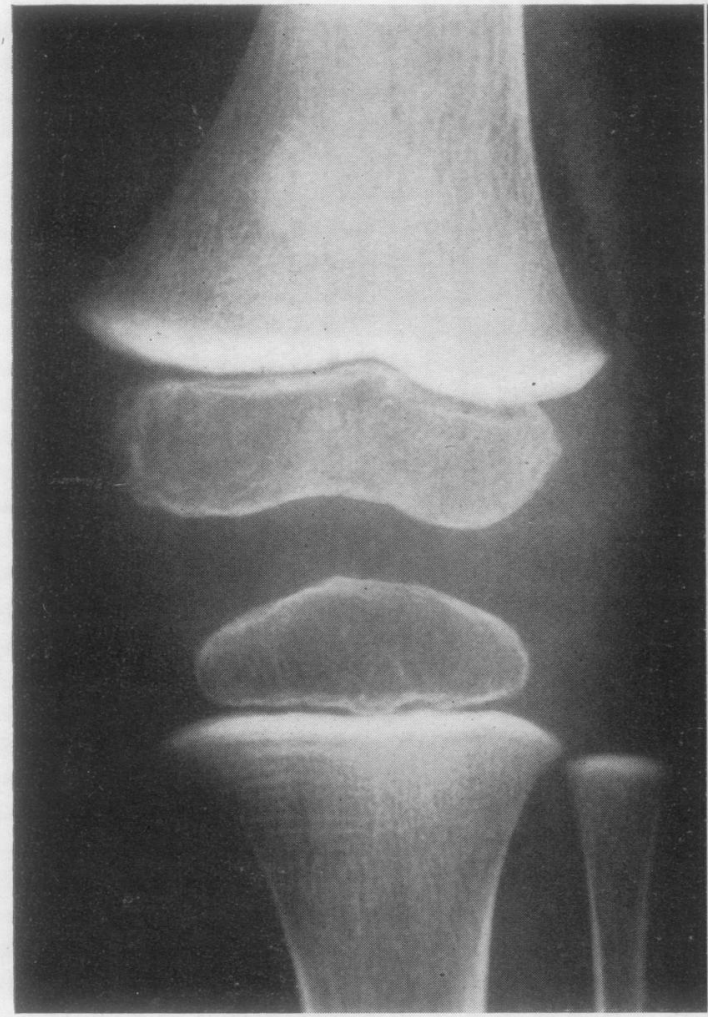

4 months after onse

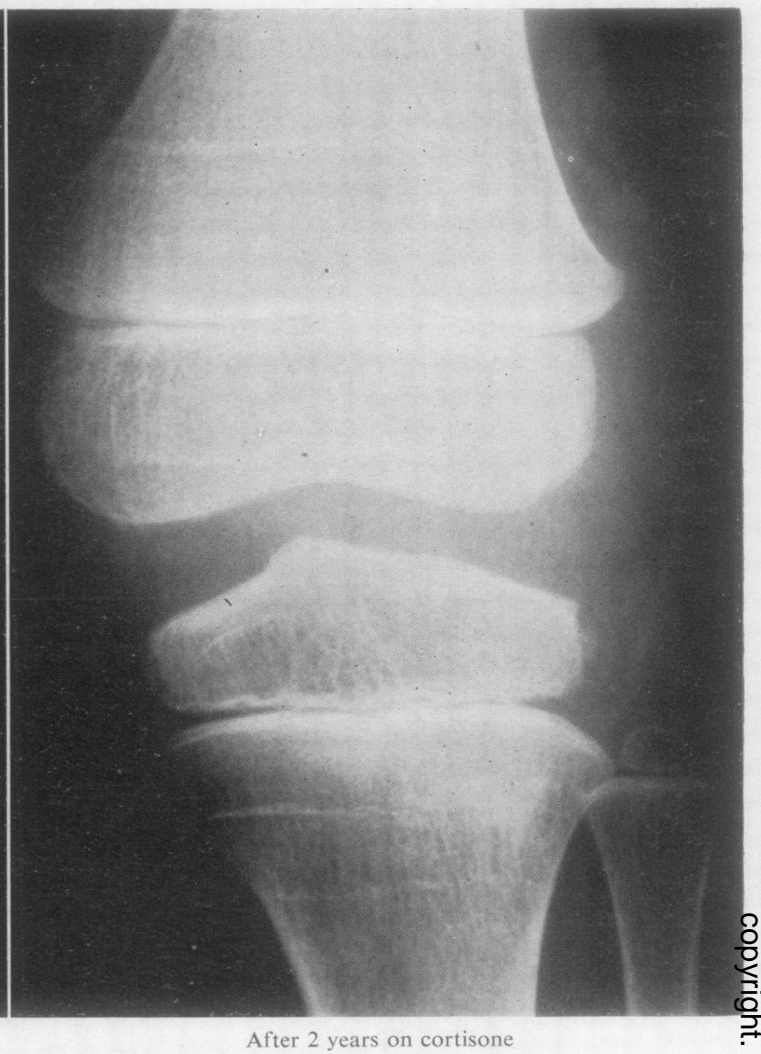

After 2 years on cortisone
Another curious radiological phenomenon was the appearance of dense wide bands beneath the epiphyseal line (Fig. 22), somewhat resembling lead or bismuth lines (Caffey, 1937) or the phosphorus lines of the older literature (Phemister, 1918), and recalling the dense bands produced in rats on very large doses of cortisone (Follis, 1951). This was seen in three cases; it was present in one child on admission to hospital, in all bones, and disappeared one month later, never to reappear. It appeared in another child while under observation and lasted a considerable time; in a third child it was present on admission but disappeared rapidly when normal mobility was obtained under cortisone therapy. Investigations for lead in this case were negative. No history of excessive vitamin D dosage, or of lead, bismuth, or other metal intoxication was obtained in any of the cases and it seems possible that this is more akin to the dense bone which is seen in cases of myxoedema who are given thyroid (Hofmeister, 1897; Goetzky and White, 1914).

(4) Unilateral Wrist Involvement.-Although many patients have involvement of one wrist initially, this asymmetry is usually short-lived, and most $\stackrel{\circ}{\triangle}$ cases ultimately become symmetrically involved. In $\rightarrow$ cases with a considerable interval before the second wrist involvement, an opportunity is afforded for $N$ comparison with an unaffected wrist, although it must be remembered that growth on this seemingly 0 normal side may be influenced by general changes $\omega$ due to the disease. 
Left
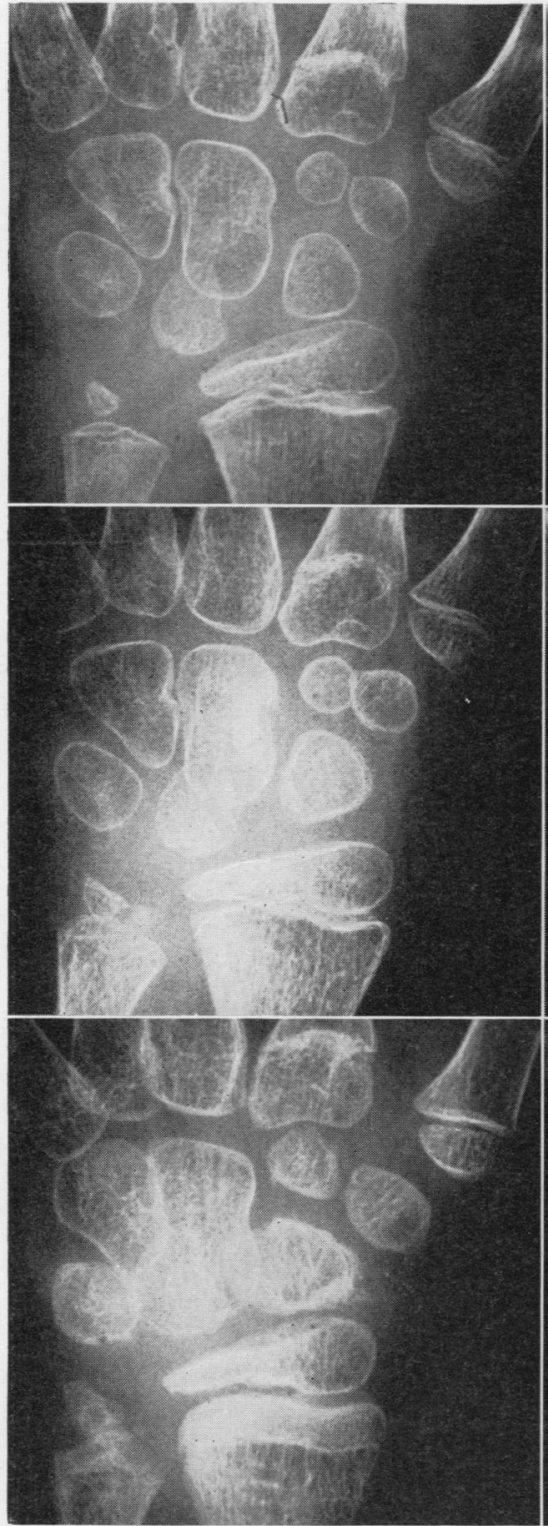

Right

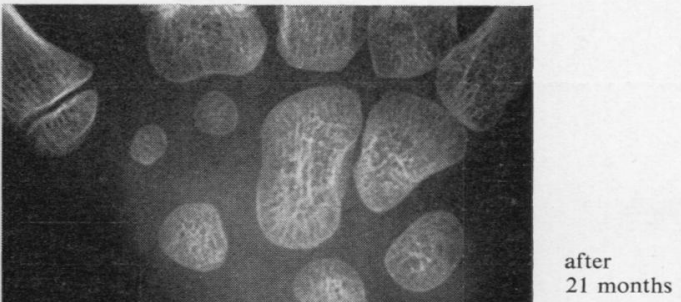

21 months

after

23 months

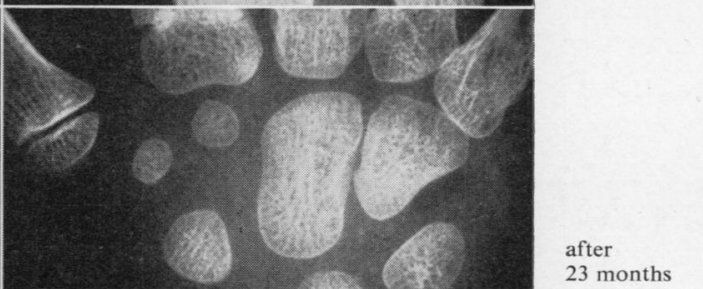

30 months

Fig. 23.-Case 3 from Table IV. Boy aged 9, with left carpal involvement, showing retardation of epiphyseal development on both sides. This retardation is much less marked on the affected side, which remains about 1 year behind the real age, while the unaffected side is 2 years behind the real age.

In the present series there were five children in whom only one wrist was involved for any considerable time; the period of involvement varied between 1 and 6 years. The unaffected side was chronologically equivalent to the actual age or was retarded by about 1 year. In all cases the carpal epiphysis on the affected side developed and remained in advance of the non-affected side by about 1 year (Fig. 23; Table IV, overleaf). 
TABLE IV

CARPAL BONE AGE IN CASES WITH UNILATERAL INVOLVEMENT, COMPARED WITH ACTUAL AGE

\begin{tabular}{|c|c|c|c|c|c|c|}
\hline \multirow[t]{2}{*}{$\begin{array}{l}\text { Case } \\
\text { No. }\end{array}$} & \multicolumn{2}{|c|}{$\begin{array}{c}\text { Duration } \\
\text { of Carpal } \\
\text { Involvement }\end{array}$} & \multicolumn{2}{|c|}{$\begin{array}{c}\text { Actual } \\
\text { Age }\end{array}$} & \multicolumn{2}{|c|}{ Bone Age } \\
\hline & Years & Months & Years & Months & Uninvolved & Involved \\
\hline \multirow{4}{*}{1} & 1 & 6 & 6 & 9 & 7 & 8 \\
\hline & 2 & 8 & 7 & 11 & $8-9$ & $9-10$ \\
\hline & 4 & 8 & 9 & 11 & 10 & 11 \\
\hline & 5 & 6 & 10 & 9 & 11 & $\begin{array}{c}\text { Fusion of } \\
\text { Carpus }\end{array}$ \\
\hline \multirow{3}{*}{2} & 2 & 0 & 7 & 0 & 6 . & 7 \\
\hline & 3 & 0 & 8 & 0 & 7 & 8 \\
\hline & 4 & 0 & 9 & 0 & 9 & 10 \\
\hline \multirow{4}{*}{3} & 1 & 6 & 9 & 6 & 6 & 7 \\
\hline & 2 & 3 & 10 & 3 & 7 & 9 \\
\hline & 3 & 2 & 11 & 2 & 9 & $10-11$ \\
\hline & 5 & 0 & 13 & 0 & 11 & $12 \frac{1}{2}$ \\
\hline \multirow{5}{*}{4} & 0 & 1 & 14 & 0 & 13 & 13 \\
\hline & 0 & 7 & 14 & 6 & 13 & 14 \\
\hline & 0 & 10 & 14 & 9 & 13 & 15 \\
\hline & 1 & 1 & 15 & 0 & 14 & 16 \\
\hline & 2 & 1 & 16 & 0 & 14 & 17 \\
\hline 5 & 3 & 0 & 15 & 0 & 15 & 16 \\
\hline
\end{tabular}

In two cases all the epiphyses of the terminal interphalangeal joints (which were uninvolved) were markedly advanced compared with the unaffected side and were also in advance of the age of the child. In one of these two cases the sesamoid of the thumb o? also showed this phenomenon, appearing fifteen $\bar{C}$ months in advance of the opposite side.

In this and other cases the bones of the affected $\frac{\bar{\sigma}}{\bar{m}}$ arm were shorter than in the contra-lateral normal $\stackrel{\mathbb{\Omega}}{\Omega}$ arm.

In two cases there was excessive hirsutism on the affected side.

(5) Jaw Development.-One of the most arresting features of Still's disease is the maldevelopment of the lower jaw (Fig. 24). This was noticed to be? present in 22 out of 152 cases of 16 years or under $\vec{F}$ at onset, seven being male. A receding chin is $\vec{t}$ sometimes seen in normal children but is seldom of $C$ marked degree. Thus, in only one of a series of 913 o children with rheumatic fever seen between 1947 and 1955 was it marked enough to be noted, although $\vec{\square}$ a space is specifically allocated to this point both $\mathbb{D}$ on the routine examination form in use here, and $\stackrel{\Phi}{3}$ on the analytical index kept by the registrar dis-

Fig. 24.-Maldevelopment of jaw in Still's disease starting at age of 31 years; present age 11 years.
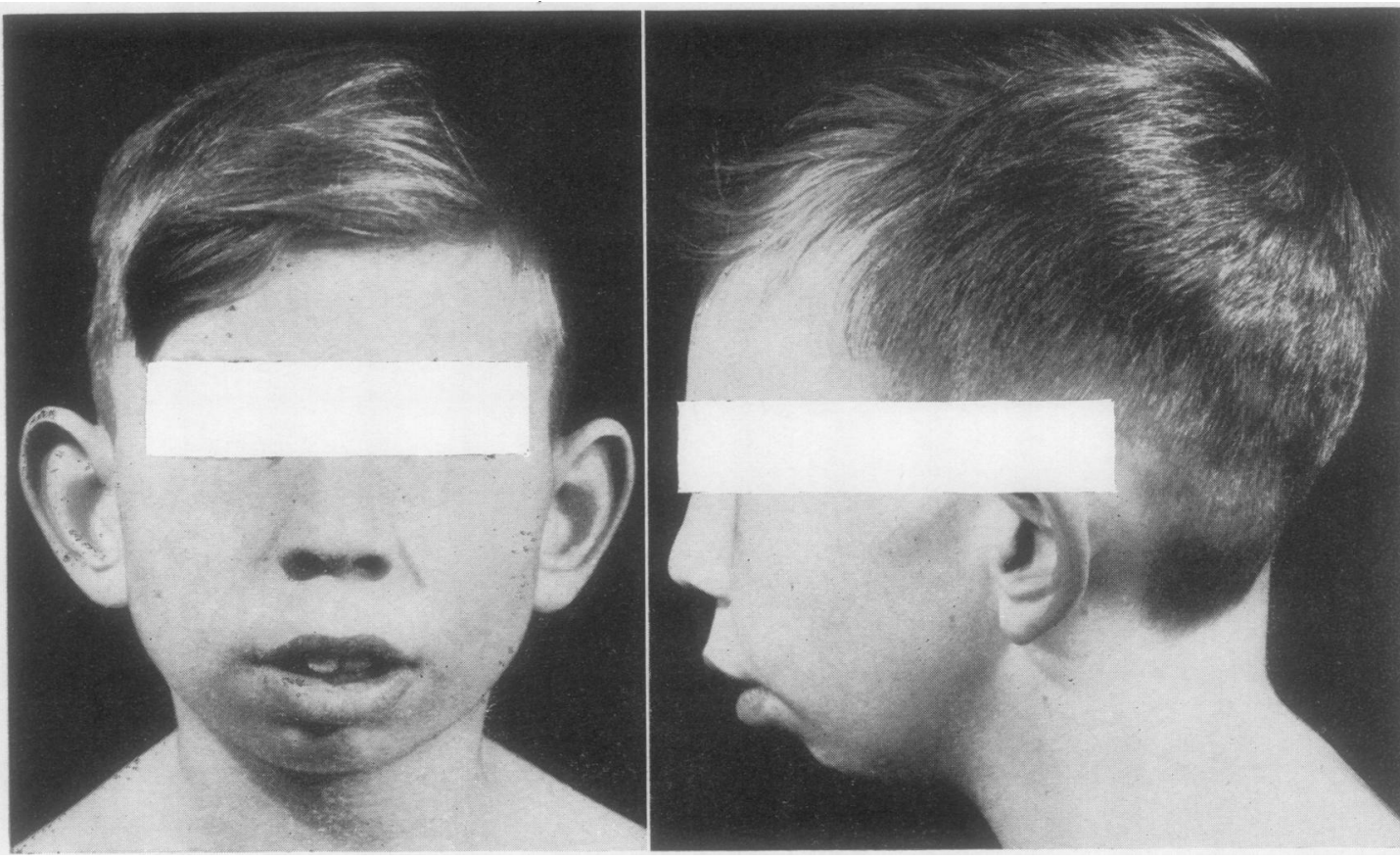
charging each case. This was not always associated with permanent involvement of the temporomandibular joints as evidenced by limitation of jaw separation, but it is difficult clearly to exclude previous involvement of this joint.

(6) Sexual Maturity.-In moderately severe cases there was some retardation in the development of secondary sexual characteristics. One child showed slight precocity in pubic hair formation, which was marked at 11 years; she had not received any hormone therapy.

(7) Effect of Hormone Therapy on Weight and Height.-All six children given methyl testosterone gained weight; this was particularly marked in those whose disease was becoming inactive (Fig. 25). Another patient not included in this series because
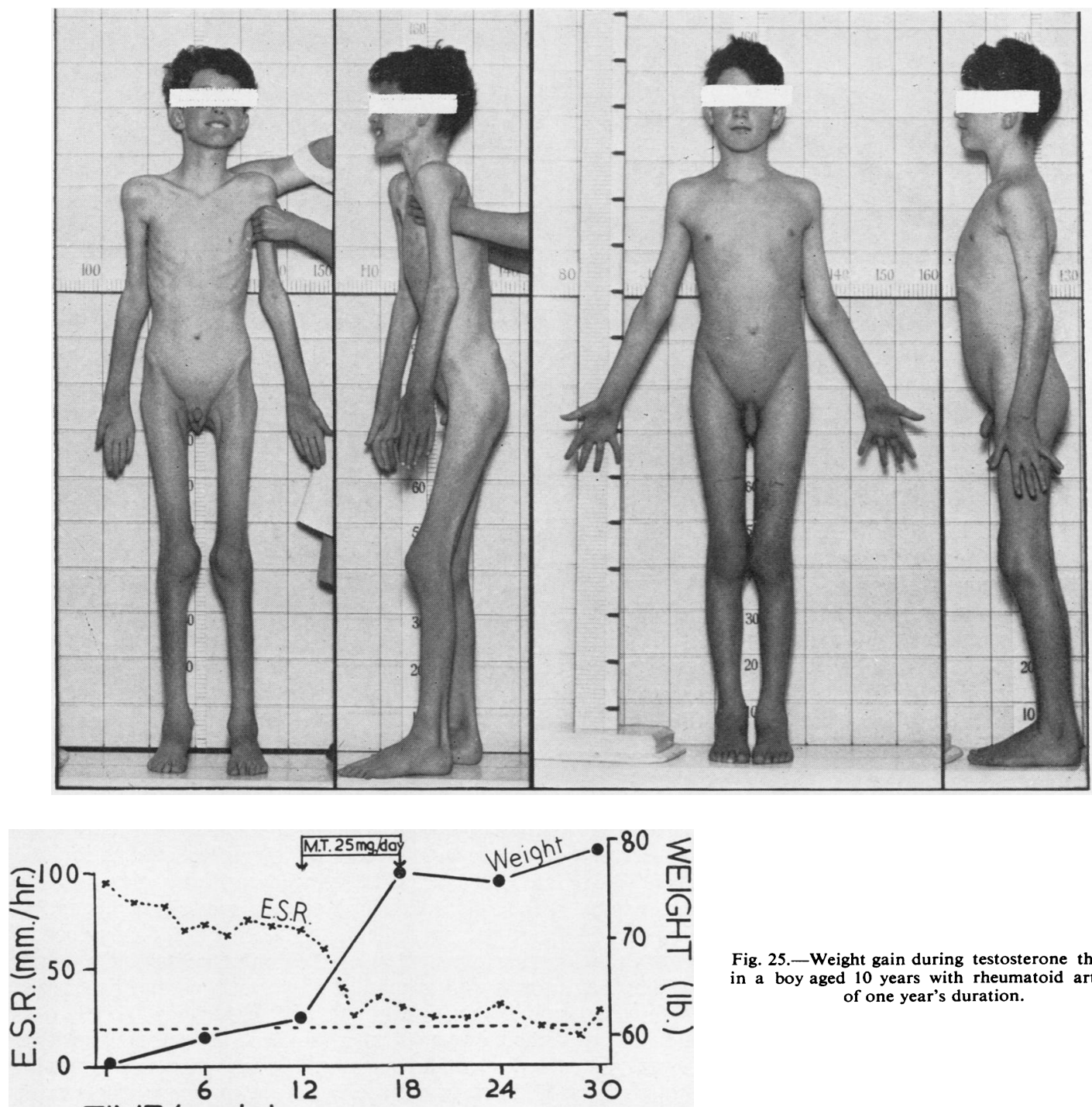

Fig. 25.-Weight gain during testosterone therapy in a boy aged 10 years with rheumatoid arthritis of one year's duration. 


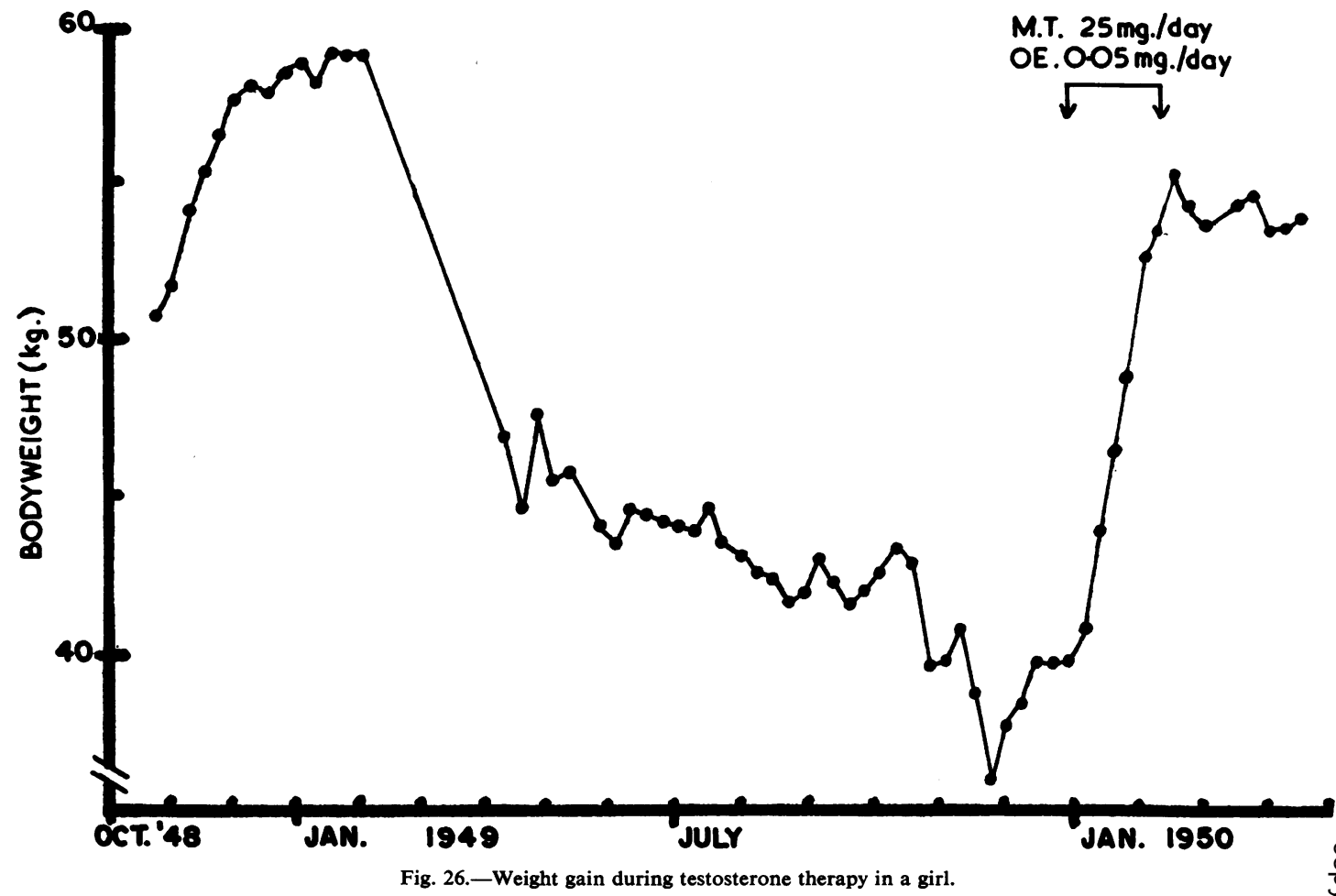

she was 15 years old at onset and 16 when treated, showed an even more striking effect (Fig. 26). In the short period of 6 to 12 weeks that hormone therapy was given, there was no effect on height or on bone age of the carpus.

With cortisone therapy there was a rapid gain in weight, and despite mild dietary restriction, the majority of the early cases treated became more than 10 per cent. overweight. When hormone was stopped because the disease became inactive (seven cases), the weight fell to normal levels (Fig. 27, opposite).

i In both early and late cases, long-term cortisone therapy was usually associated with a failure to grow in height despite good clinical control of the disease. In children under 5 years of age, dosage of 37.5 mg./day and over seemed to inhibit growth, while in the older age group this critical level appeared to be $50 \mathrm{mg}$./day (Fig. 28, overleaf). Once the dosage was reduced growth was resumed despite clinical activity; see Fig. 28D where cortisone was stopped because of complications.

In patients receiving cortisone, there was no apparent effect on bone development, although in the young, some prematurity, which was present initially, persisted despite control of activity of the disease. Two cases have shown definite radiological progression of the disease (Fig. 29, overleaf) despite the fairly satisfactory clinical control.

\section{Discussion}

Although Cornil (1864) described chronic arthritis occurring in children, Still (1897), in his classical description of the disease, was the first to note the general arrest of development. Following this, there were numerous single case reports, such as that of Hoppe-Seyler (1903), who described a 23-year-old woman with marked shortening of the limbs, assumed to be due to her arthritis which had begun at the age of 7 years. Other case reports include that of Dock (1912), who described a man aged 24 who had reduced limb growth due to arthritis dating from the age of 11. Eliakim (1922) described a similar shortening of the limbs, particularly in the forearms, in a man of 58 years in whom the disease had begun at the age of 9 . Algyogyi (1909) described dwarfism in a 20-year-old woman in whom the disease had begun at 6 years. Kuhns and Swaim (1932) reviewed the literature on growth defects in chronic arthritis and described twelve of their own 

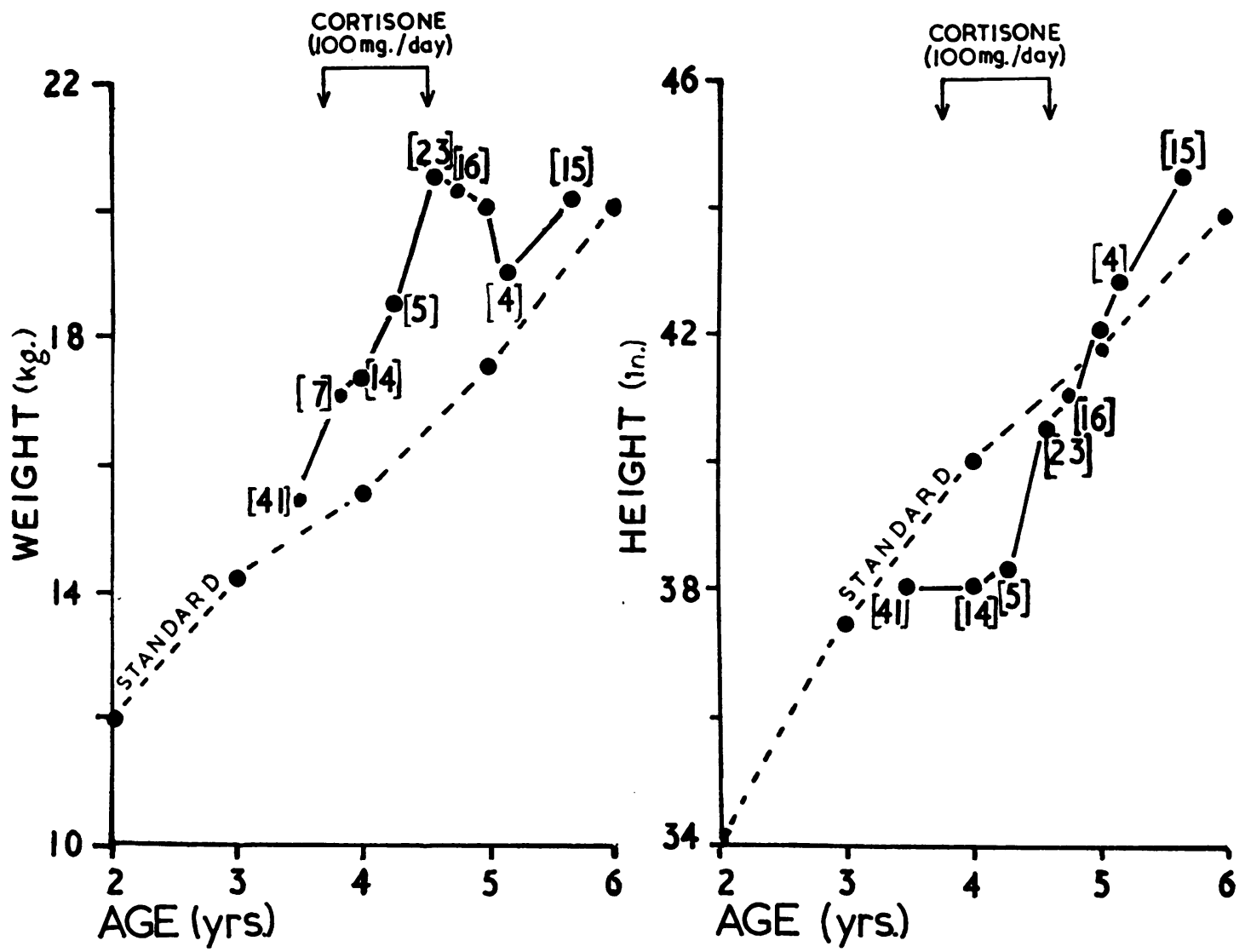

Fig. 27. - Suppression of disease by cortisone was accompanied by a rapid gain in weight. Restoration of growth as height was not seen initially on cortisone and occurred only when the disease activity subsided.

cases. They felt that these disturbances of growth could be divided into three types: a generalized retardation of body growth, a persistence of the infantile appearance and proportions of the extremities, and asymmetry of growth. This suggested that the type of disturbance depends on the severity and location of the disease. As more cases were reported, these defects were seen to be not uncommon; thus four of the 28 cases described by Lockie and Norcross (1948) had interference with bone growth, and 22 of the fifty cases described by Coss and Boots (1946) showed a disturbance of the skeletal pattern, the two most frequent abnormalities encountered being brachygnathia and brachydactylia. Both accounts agreed that these deformities were more likely when the disease had begun early in life. Middlemiss (1951), in a series of over forty cases, notes that the changes are more frequent later in the disease.

In our cases; the failure of normal growth in height and weight was closely associated with the activity of the disease, occurring early and tending to correct itself as the disease became inactive, so that only in long-standing cases was there severe general stunting in the absence of premature fusion of epiphyses. The commonest radiological evidence of growth disturbance were growth lines in the metaphyses, which might occur equally in the radius for instance, in those with and without wrist involvement. These lines are due to temporary arrest of cartilaginous growth and are entirely non-specific, having originally been described in Great Britain by Harris (1933) in various acute illnesses, particularly broncho-pneumonia. Hewitt, Westropp, and Acheson (1955) recently emphasized the frequency with which these occur in healthy children as the result of minor ailments. Most of the bizarre growth anomalies in our series developed as a result of local disease and were due directly to premature fusion of the epiphyses. Premature epiphyseal fusion occurred more commonly in the older age group, and affected particularly the metacarpal 


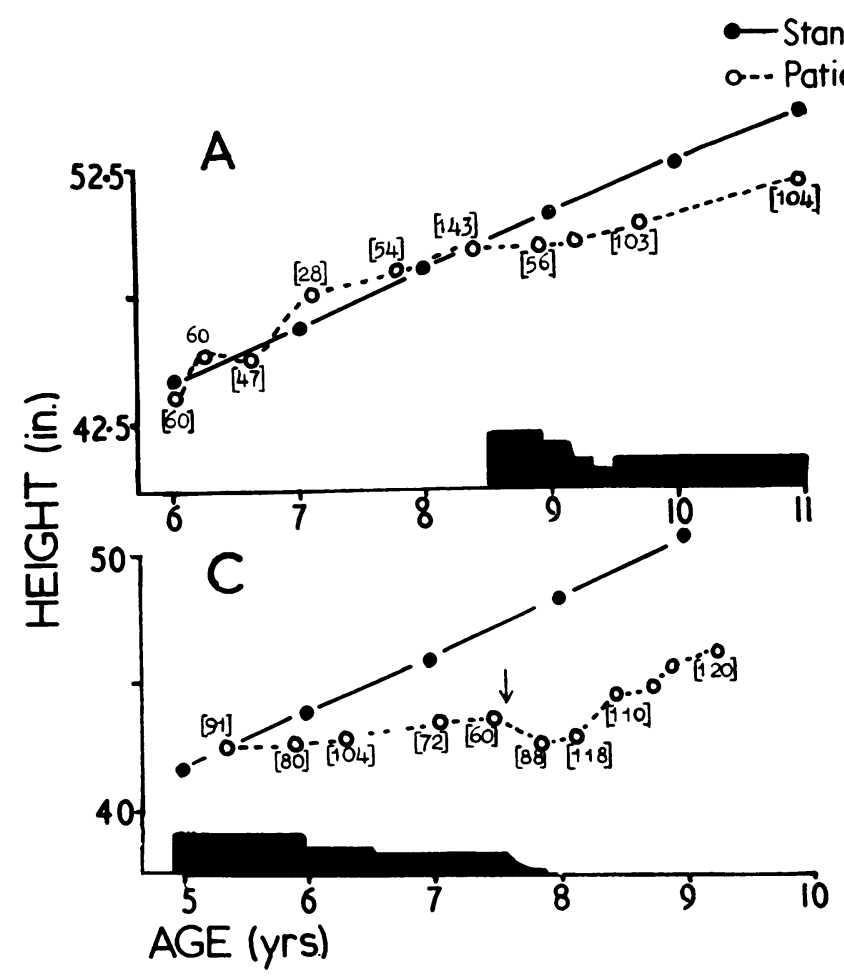

- Standard growth

so $\rightarrow$ Cortisone (mg./day)

Numeral= E.S.R. $(\mathrm{mm} / \mathrm{hr}$.
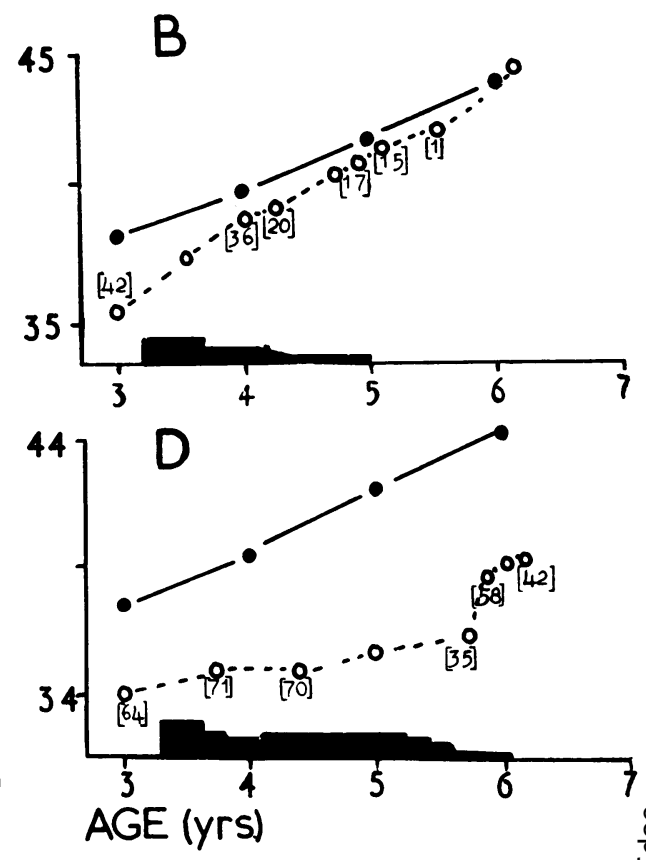

Fig. 28.-Effect of prolonged cortisone therapy on the rate of growth as height in children.

(A) Male, onset at $2 \mathrm{yrs}$ with severe relapse at $8 \mathrm{yrs} 4 \mathrm{mths}$ when cortisone therapy was begun.

(C) Female, onset at $15 \mathrm{mths}$, persistent activity for $11 \mathrm{mths}$ before cortisone therapy was begun. $\downarrow=$ crush fracture of vertebra.

bones and phalanges. Our results are in general agreement with those of Coss and Boots (1946) in that the most severe deformities are seen when the disease commences early in life and continues for a long period, but we have found that the most frequent deformity, brachydactylia, is more common in the older age group and may occur fairly quickly. Short of premature fusion, there was no obvious difference between the cases which showed advancement and those who showed retardation of epiphyseal development in the affected limb. However, in all five cases with unilateral wrist involvement, the unaffected side was retarded in comparison with the affected side and with chronological age as described by Françon, Forestier, and Robert (1937). Metaphyseal growth was sometimes increased on the affected side in comparison with the unaffected side in immobilized cases.

The mechanism of these disturbances of growth is unknown. In the healthy, well-fed child, growth proceeds until shortly after puberty. The rate of growth would appear to be under the control of the
(B) Female, onset at 2 yrs 9 mths, mild activity well controlled by small doses of cortisone.

(D) Female, onset at $1 \mathrm{yr}$, persistent marked activity with fever until cortisone therapy was begun.

pituitary growth hormone, but its cessation is largely determined by the time of epiphyseal union. The cause of growth cessation is unknown, and may be due either to a factor which inhibits the growth hormone, or to one which works on the end organs.

In juvenile rheumatoid arthritis, marked defects of general growth are seen only in severe cases and it could be that the disease causes inhibition of the pituitary growth factor. In favour of this is the delayed development of secondary sex characteristics, which is common in these cases, but there are no other signs of pituitary failure, and in six of our patients between the ages of 7 and 14 years, who showed general stunting, the excretion of 17-ketosteroids was within the range of normal values for children given by Talbot, Butler, Berman, Rodriguez, and MacLachlan (1943). Even if the general growth failure were due to pituitary failure, it could not account for the local variation in epiphyseal development. This fact is particularly clear in patients with unilateral wrist involvement. Here in all cases the affected wrist was in advance of the 


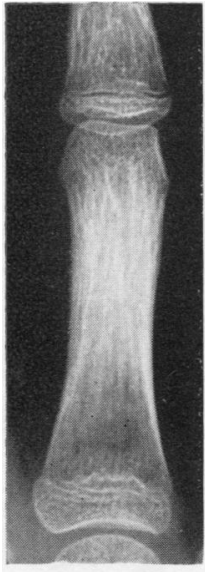

5 months

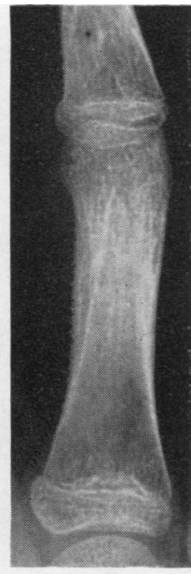

10 months

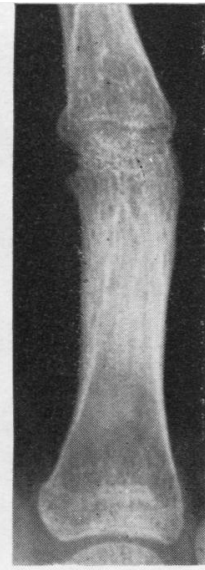

15 months
Fig. 29.-Progression of erosion in proximal interphalangeal joint at 5,10 , and 15 months from onset, cortisone being given in suppressive dosage from the fifth month.

unaffected one, which might or might not be retarded. Thus one would have to postulate a generalized inhibiting factor due to the disease itself and a local accelerating factor due to local joint involvement. That a local factor is at work is suggested by the hirsutism seen on the affected limb. It might be postulated that the increased vascularity resulting from active joint involvement which produces the local rise in temperature over an involved joint and affects the skin and soft tissues, could also affect the bone and thus cause bony overgrowth; this is well recognized as a local consequence of haemangiomata, cirsoid limb aneurysms, and arterio-venous fistulae (Ward and Horton, 1940).

The cause of premature fusion of epiphyses is also unknown. In tuberculosis of the hip, premature closure of the epiphyseal cartilage of the lower end of the femur where there is marked decalcification has been described (Gill, 1944; Ross, 1948). It is also suggested that immobility causes degeneration of the epiphyseal cartilage with subsequent bridging (Sissons, 1952). Osteoporosis occurs early in the course of rheumatoid arthritis and, when joints are severely affected, that limb is frequently kept at rest. However, fusion can also occur without either of the above factors being present.

Although patients put on weight on cortisone therapy, normal growth as height was not resumed until the cortisone was reduced below a certain critical level either because the disease became inactive or because of toxic complications or other reasons.

Bunim, Ziff, and McEwen (1955) found that prolonged hormone therapy in Still's disease allowed growth as height to return to normal levels in five out of eight cases, in only one of whom had they been able to discontinue cortisone therapy. As he does not state his dosage, however, this experience does not necessarily conflict with ours. This slowing of children's growth has also been shown to occur with cortisone in several endocrine diseases of childhood and in allergy (Blodgett, Burgin, lezzoni, Gribetz, and Talbot, 1956). Using the Greulich-Pyle standard, they also noted that the rate of skeletal maturation in eleven children with congenital hypercortical activity was decreased from their previously increased levels. Our findings of decreased growth as height with little effect on skeletal maturation during cortisone therapy rather resemble those described by Hewitt and others (1955) in intercurrent illness.

The courses of testosterone we gave were too short to influence bony development. In all instances there was weight gain and this was particularly marked when the disease was becoming less active.

We conclude that in Still's disease there is a general retardation of growth affecting both height and weight, as in other chronic diseases of childhood either inflammatory or metabolic.

Skeletal maturation is, however, not beyond a range of one year from real age, unless local disease is present. Local disease may lead to increased or decreased metaphyseal growth rates, to premature epiphyseal development, and sometimes to premature fusion.

Steroid therapy above a certain dosage inhibits growth in height but not skeletal maturation.

\section{Summary}

Changes in height, weight, and bone growth have been followed over a period of years in 119 cases of Still's disease (defined for this purpose as rheumatoid arthritis starting before the age of 14 years). Abnormality was defined by comparison with published normal standards and with a small series of rheumatic fever patients.

Height was temporarily decreased more than 10 per cent. below normal in about half the children measured, but in many of the younger children, when the disease became quiescent, growth was rapidly resumed and returned to the standard level. Weight was lost at onset, remained low during disease activity, and resumed normal levels with quiescence. Only with fever and prolonged disease activity were marked residual defects in height and weight observed.

In children without hand involvement, carpal maturity was within one-year limits of normality, 
but in half the cases where the carpus or wrist were involved, carpal development was advanced.

Abnormalities of bone development occurred primarily in the neighbourhood of the affected joints. These included premature epiphyseal fusion, particularly in the older group, leading to shortened bones, increase in epiphyseal size and in longitudinal growth of the metaphysis, temporary decrease or arrest of bone growth manifest as growth lines and double-contoured epiphyses, and minor changes such as periostitis, dense metaphyseal bands, and subchondral bony outgrowths of the epiphyses.

These changes can be ascribed to a general nonspecific retardation of growth, such as is seen in any long-standing generalized disease of childhood, and to a local effect in the neighbourhood of involved joints, possibly due to increased blood flow, which produces a temporary acceleration of development and sometimes of growth, but more usually a decreased growth rate or premature epiphyseal fusion.

Male sex hormone over short periods caused in some children a rapid gain in weight which was maintained; cortisone therapy over prolonged periods produced the usual temporary obesity and a slowing of growth in height at all but minimal levels of dosage. There was little apparent effect on skeletal maturation.

\section{REFERENCES}

Adams, F. H., and Forsyth, W. B. (1951). J. Pediat., 39, 330. Algyogyi, H. (1909). Mitt. Ges. inn. Med. Wien, 8, 103. Barkin, R. E. (1952). Bull. rheum. Dis., 3 (no. 1), p. 19.

Beal, C. K. (1948). J. Pediat., 32, 170.

Blodgett, F. M., Burgin, L., Iezzoni, D., Gribetz, D., and Talbot, N. B. (1956). New Engl.J. Med., 254, 636.

Bogan, I. K. (1940). Amer. J. Dis. Child., 59, 805

Bunim, J. J., Ziff, M., and McEwen, C. (1955). Amer. J. Med., 18, 27 .

Bywaters, E. G. L. (1948). Annals of the Rheumatic Diseases, 7, 24. Campbeli, M., and Reynolds, G. (1949). Arch. Dis. Child., 24, 294. Caffey, J. (1937). Amer. J. Dis. Child., 53, 56.

Cohen, M. B., and Abram, L. E. (1948). J. Allergy, 19, 165. Weller, R. R., and Cohen, S. (1940). Amer. J. Dis. Child., $60,1058$.

Cornil, V. (1864). Mém. Soc. Biol. (Paris), Ser. 4, 1, 3.

Coss, J. A., and Boots, R. H. (1946). J. Pediat., 29, 143.

Daley, A. (1950). London County Council, No. 3692. "Report on the Heights and Weights of School Pupils in the County of London in 1949."

Dennison, W. M. (1952). Arch. Dis. Child., 27, 54.

Dock, G.'(1912). Amer. J. med. Sci., 144, 469.

Edström, G. (1947). Acta paediat., 34, 334.

Edstrom, G. (1947). Acta paediat., 34, 334.

Eliakim, S. (1922). Z. Kinderheilk., 33, 55.

Ellis, A., and Evans, H. (1933). Quart. J. Med., 2, 231. 71

Follis, R. H., Jr. (1951). Proc. Soc. exp. Biol. (N.Y.), 76, 722.

Françon, F., Forestier, J., and Robert, P. (1937). J. Radiol. Electrol., 21, 5 .

Gaunt, R. T. (1949). Lancet, 1, 1049.

Gill, G. G. (1944). J. Bone Jt Surg., 26, 272

Goetzky, F., and White, F. (1914). Z. Kinderheilk., 11, 179

Goetzky, F., and White, F. (1914). Z. Kinderheilk., 11, 179. J. Pediat., 43, 121.

and Pyle, S. I. (1950). "Radiographic Atlas of Skeletal Development of the Hand and Wrist, based on the Brush Foundation Study of Human Growth and Development initiated by T. Wingate Todd." University Press, Stanford, California.

Halbertsma, T. (1933). Amer. J. Dis. Child., 46, 1356.
Harris, H. A. (1933). "Bone Growth in Health and Disease." Oxford University Press, London.

Harris, R. I. (1930). J. Bone Jt Surg., 12, 859.

Hernberg, C. A., and Heikel, P. E. (1951). Acta paediat., 40, 486.

Hewitt, D. Westropp, C. K . E. (1951). Acta paediat., 40, 486. prev. soc. Med., 9, 179.

Hofmeister, F. (1897). Fortschr. Röntgenstr., 1, 4

Holt, L. E., Jr., and McIntosh, R. (1941)." "Holt's Diseases of Infancy and Childhood", 11 th ed. Appleton-Century, New York.

Hoppe-Seyler, G. (1903). Dtsch. Arch. klin. Med., 75, 320.

Kuhns, J. G., and Swaim, L. T. (1932). Amer. J. Dis. Child., 43, 1118 Langston, W. (1935). Sth. med. J., 28, 316.

Lockie, L. M., Norcross, B. M. (1948). Pediatrics, 2, 694

Lund, G. W. (1952). J. Pediat., 41, 572.

Mainland, D. (1953). Pediatrics, 12, 114

Menzies, F. (1940). London County Council, No. 3464. "Report by the School Medical Officer on the Average Heights and Weights of Elementary School Children in the County of London in 1938."

Middlemiss, J. H. (1951). Proc. roy. Soc. Med., 44, 805

Paget, J. (1853). "Lectures on Surgical Pathology", vol. 1. Longmans, London.

Phemister, D. B. (1918). J. Amer. med. Ass., 70, 1737.

Ross, D. (1948). J. Bone Jt Surg., 30A, 103.

Sissons, H. A. (1952). Ibid., 34B, 275.

Still, G. F. (1897). Med.-chir. Trans., 80, 47 (reprinted in Arch. Dis. Child., 1941, 16, 156).

Talbot, N. B., Butler, A. M., Berman, R. A., Rodriguez, P. M., and MacLachlan, E. A. (1943). Amer. J. Dis. Child., 65, 364.

Sury, B. (1952). "Rheumatoid Arthritis in Children: a Clinical Study." Munksgaard, Copenhagen.

Ward, C. E., and Horton, B. T. (1940). J. Pediat., 16, 746.

Welsh, J. B. (1951). Ibid., 38, 571.

\section{La croissance dans la maladie de Still}

\section{RÉSUMÉ}

Les modifications de taille, de poids et de croissance des os ont été suives durant plusieurs années, dans 119 cas de maladie de Still (définie en l'occurence comme arthrite rhumatismale survenant avant l'âge de 14 ans) Les anomalies ont été définies par comparaison avec des standards normaux publiés et avec un petit groupe de malades atteints de rhumatisme articulaire aigu.

La taille était temporairement diminuée de plus de $10 \%$ au-dessous de la normale chez environ la moitié des enfants mesurés, mais chez beaucoup d'enfants plus jeunes la croissance reprenait et revenait rapidement au niveau normal dès l'arrêt de l'activité morbide. Le poids, perdu au début, demeurait bas à la période évolutive et remontait au niveau normal à la période de rémission. Seulement dans les cas de fièvre et d'activité morbide prolongée pouvait on observer des défauts résiduels marqués de taille et de poids.

Chez les enfants dont les mains n'étaient pas atteintes, la maturité du carpe se trouvait à une année près de la normale, mais dans le moitié des cas où le carpe ou le poignet se trouvait atteint, le développement carpien était avancé.

Des anomalies de développement osseux se produisaient d'abord au voisinage des articulations atteintes. Elles comprenaient: la fusion épiphysaire prématurée, en particulier chez les enfants plus âgés, ce qui conduisait à un racourcissement osseux; accroissement de l'épiphyse et allongement de la métaphyse; une diminution ou l'arrêt temporaire de la croissance osseuse, manifestes sous formes de lignes de croissance et d'épiphyses à double contour, et des altérations mineures, telles que périostite, bandes métaphysaires denses et excroissances osseuses souschondrales des épiphyses.

Ces altérations peuvent être imputées à un retard généralisé, non-spécifique, de la croissance, tel qu'on peut en observer dans n'importe quel cas de maladie généralisée et de longue durée de l'enfance, et à un effet local dans le voisinage des articulations atteintes, 
probablement dû à une plus forte irrigation sanguine, produisant une accélération temporaire du développement et parfois de la croissance, mais plus souvent un rhythme de croissance diminuée ou une fusion épiphysaire prématurée.

L'hormone sexuelle mâle administrée durant de courtes périodes produisait chez quelques enfants un gain rapide de poids qui était maintenu; la thérapie stéroide sur des périodes prolongées produisait l'obésité temporaire habituelle et un ralentissement de l'augmentation de taille à tous les dosages, sauf en quantité minime. Il y avait peu d'effet apparent sur la maturation du système ostéo-musculaire.

\section{El crecimiento en la enfermedad de Still}

\section{Sumario}

Las modificaciones de estatura, peso y crecimiento óseo fueron seguidas duranto algunos años en 119 cases de énfermedad de Still (definida aquí como artritis reumatoide empezando antes de la edad de 14 años). Las anomalías fueron definidas en comparación con normas publicadas y con un pequeño grupo de enfermos con reumatismo poliarticular agudo.

La estatura fué temporariamente disminuida de más de $10 \%$ de la norma en cerca de la mitad de los niños medidos, pero en muchos niños jóvenes en el período de quietud de la enfermedad hubo un reanudo rápido del crecimiento hasta alcanzar la norma. El peso perdido al principio de la enfermedad quedaba bajo durante la actividad mórbida pero subía al nivel normal durante el período de quietud. Tan sólo en casos de fiebre y de actividad mórbida prolongada pudiéronse observar defectos residuales marcados de estatura y de peso.

En los niños cuyas manos no fueron implicadas, el estado madurativo del carpo se alejaba de un año de la norma, pero en la mitad de los cases de implicación del carpo o de la muñeca el desarrollo del carpo estaba adelantado.

Anomalías de desarrollo óseo producíanse primeramente cerca de las articulaciones implicadas. Estas comprendían: fusión epifisaria prematura, en particular en niños mayores, lo que producía huesos más cortos; agrandecimiento de la epífisis y crecimiento longitudinal de la metáfisis; disminución o interrupción temporaria del crecimiento óseo, manifestándose en líneas de crecimiento y en epífisis con doble contorno; y alteraciones menores, como periostitis, fajas metáfisarias densas y excrecencias óseas subcondrales de las epífisis.

Estas alteraciones pueden atribuirse a un atraso generalizado, no específico del crecimiento, de tipo que se puede notar en cualquier caso de enfermedad generalizada y persistente de la infancia, y a un efecto local alrededor de las articulaciones implicadas, probablemente a conseciencia del riego sanguíneo aumentado con acceleración temporaria del desarrollo y a veces del crecimiento, pero más a menudo con ritmo de crecimiento disminuido o con fusión epifisaria prematura.

La hormona sexual masculina administrada durante períodos cortos producía en algunos niños un aumento de peso que se mantenía. La terapia esteroide prolongada conducía a la obesidad temporaria habitual y al retraso de crecimiento de la estatura con todas las dosis, exceptuando las dosis mínimas. No hubo efecto aparente sobre la maduración del sistema óseo-muscular. 